\title{
Summer hydrographic changes in the Baltic Sea, Kattegat and Skagerrak projected in an ensemble of climate scenarios downscaled with a coupled regional ocean-sea ice-atmosphere model
}

\author{
M. Gröger ${ }^{1}$ D $\cdot$ L. Arneborg ${ }^{1,2} \cdot$ C. Dieterich ${ }^{1} \cdot$ A. Höglund ${ }^{1} \cdot$ H. E. M. Meier ${ }^{1,3}$
}

Received: 11 September 2018 / Accepted: 18 July 2019 / Published online: 1 August 2019

(c) The Author(s) 2019

\begin{abstract}
This model study investigates summer hydrographic changes in response to climate projections following the CMIP5 RCP8.5 scenario. We use the high resolution regional coupled ocean-sea ice-atmosphere model RCA4-NEMO to downscale an ensemble of five global climate projections with a main focus on the Baltic Sea and neighboring shelf basins to the west. We find consistently across the ensemble a northward shift in the mean summer position of the westerlies at the end of the twenty-first century compared to the twentieth century. Associated with this is an anomalous precipitation pattern marked by increased rainfall over northern Europe and dryer conditions over the continental central part. In response to these largescale atmospheric changes, a strong freshening mainly resulting from a higher net precipitation over the year combined with higher annual mean runoff is registered for the Baltic Sea and adjacent seas. The strongest freshening takes place in the southern Skagerrak region where stronger winds enhance the cyclonic circulation and by this, recirculation of fresher waters from the Baltic Sea strengthens. In the Baltic Sea freshening leads to a reduction in basin averaged salinities between 0.6 and $2.3 \mathrm{~g} \mathrm{~kg}^{-1}$ throughout the ensemble. Likewise, the sea surface temperature response in the Baltic Sea varies between +2.5 and $+4.7 \mathrm{~K}$ depending on the applied global model scenario. The climate induced changes in atmospheric forcing have further consequences for the large-scale circulation in the Baltic Sea. All ensemble members indicate a strengthening of the zonal, wind driven near surface overturning circulation in the southwestern Baltic Sea towards the end of the twenty-first century whereas the more thermohaline driven overturning at depth is reduced by $\sim 25 \%$. In the Baltic Proper, the meridional overturning shows no clear climate change signal. However, three out of five ensemble members indicate at least a northward expansion of the main overturning cell. In the Bothnian Sea, all ensemble members show a significant weakening of the meridional overturning. The entire ensemble consistently indicates a basin-wide intensification of the pycnocline (9-35\%) for the Baltic Sea and a shallowing of the pycnocline depth in most regions as well. In the Baltic Sea, which is dominated by mesohaline conditions under the historical period, the changes in salinity at the end of the twenty-first century have turned wide areas to be dominated by oligohaline conditions as a result of climate change. Potential consequences for biogeochemical conditions and implications for biodiversity are discussed.
\end{abstract}

Electronic supplementary material The online version of this article (https://doi.org/10.1007/s00382-019-04908-9) contains supplementary material, which is available to authorized users.

M. Gröger

matthias.groger@smhi.se

1 Swedish Meteorological and Hydrological Institute, Norrköping, Sweden

2 University of Gothenburg, Gothenburg, Sweden

3 Leibniz Institute for Baltic Sea Research Warnemünde, Rostock, Germany

\section{Introduction}

Because global climate projections are associated with high uncertainties on regional scales current efforts to provide climate information for certain regions have to be pursued in coordinated experiments and in large ensembles of high resolution regional models. For the atmosphere, this work has been organized by the CORDEX (Coordinated Regional Climate Downscaling Experiment) community as part of the Coupled Model Intercomparison Project (CMIP) which is currently in its 6th phase (Giorgi et al. 2009; Gutowski et al. 
2016). However, most of the efforts in CORDEX clearly focus on the atmosphere (e.g. Jacob et al. 2014; Berg et al. 2015; Koenigk et al. 2015; Kotlarski et al. 2015). More comprehensive assessments that involve also interactively coupled ocean and/or land models thereby allowing to realistically simulate complex feedback loops across climate compartments (e.g. Tian et al. 2013; Sein et al. 2015; Gröger et al. 2015; Sein et al. 2018) are still rare but are currently fostered within CMIP5 (Dethloff et al. 2012; Gutowski et al. 2016). For the NW European shelf, i.e. the Baltic Sea and North Sea regions the knowledge about the impact of climate change has been recently summarized in two assessments (Meier 2015; Schrum et al. 2016). However, both reports are based mainly on climate scenarios according to the Special Report on Emission Scenario (SRES) as part of the previous CMIP phase 3 (e.g. Tinker et al. 2016) while only few scenarios have so far been carried out that follow the Radiative Concentration Pathways (RCPs, e.g. Pushpadas et al. 2015; Mathis et al. 2017; Sein et al. 2018).

Depending on the chosen scenario previous studies have reported a substantial freshening and a sea surface temperature (SST) increase for the Baltic Sea (e.g. Neumann 2010; Neumann and Friedland 2011; Meier et al. 2011, 2012a, b, c; Saraiva et al. 2018, 2019). These changes are consistent with results obtained for other seas on the NW European shelf such as the North Sea (Holt et al. 2012, 2016; Gröger et al. 2013; Mathis and Pohlmann 2014; Mathis et al. 2017; Tinker et al. 2016; Schrum et al. 2016). Most of these modeling studies have applied uncoupled ocean-only models forced by either output from global climate models scenarios directly or by output from higher resolution regional atmosphere standalone models (e.g., Omstedt et al. 2012; Mathis and Pohlmann 2014; Tinker et al. 2016). Both of these strategies have in common that the atmospheric forcing fields are prescribed during the simulation and so any changes in the ocean are ignored by the atmosphere. As a result, the ocean is missing an important response from the atmosphere. However, it was shown that this strategy might be problematic. Recently, Mathis et al. (2017) have shown that such kind of one-way coupled simulations are very tightly constrained by the atmospheric forcing alone with respect to simulated SSTs while interactive coupled air-sea interaction as done in coupled regional ocean-sea ice-atmosphere models can develop more independently. Moreover, Tian et al. (2013), and Gröger et al. (2015) have shown that interactive air-sea coupling can substantially improve simulated SSTs in hindcast simulations through a realistic simulation of ocean-atmosphere feedbacks. In turn, air-sea thermal feedbacks have been found to play an important role in simulating extreme weather phenomena and interactive coupling can improve results (e.g. Ho-Hagemann et al. 2017; Jeworrek et al. 2017; van Pham et al. 2017). On the other hand, fully coupled long-term model simulations are extremely expensive especially when applied in large ensembles and in connection with computationally intensive biogeochemical models. Therefore, in order to address combined biogeochemical and climate related questions, often the output from coupled ocean-sea ice-atmosphere models is used to force standalone ocean-biogeochemical models (e.g. Meier et al. 2011, 2012a; Neumann et al. 2012). A detailed discussion about the benefit and potential problems of coupled regional modeling compared to the use of stand-alone components has been given in Schrum (2017).

In contrast to previous studies (Meier et al. 2011; Bülow et al. 2014) the present study employs for the first time more than two global earth system models at the lateral boundaries of the regional high resolution model. The analyzed ensemble is to our knowledge so far the largest ensemble of downscaled coupled climate scenarios for marginal seas on the NW European shelf.

\subsection{Brief description of the study area}

The model domain encompasses the Baltic Sea, Kattegat, Skagerrak, and also the North Sea though the latter is not the primary focus in this study (Fig. 1).

The Baltic Sea is a brackish sea and has very limited water exchange with marine water originating from the North Sea and therefore has long flushing times in the order of 2-3 decades (e.g. Meier 2007; Meier et al. 2018b). The average depth is about $50 \mathrm{~m}$. It is permanently stratified in most areas due to a strong halocline at $60-80 \mathrm{~m}$ depths (e.g. Väli et al. 2013). The Baltic Sea has been subdivided in several sub-basins based on its bathymetric configuration (Fig. 1). Salinities range from nearly full marine conditions in the westernmost parts to nearly freshwater conditions in the northernmost part. The Baltic Sea receives a large amount of freshwater from the surrounding catchment area with main rivers located north of $60^{\circ} \mathrm{N}$ (around $14,000 \mathrm{~m}^{3} \mathrm{~s}^{-1}$ in the long-term yearly average, Meier and Kauker 2003).

The Baltic Sea is connected with the North Sea by small and shallow channels in the Kattegat (Fig. 1). Together with the Danish straits this area constitutes the pathway for the more or less sporadic severe inflows of salt-rich water masses from the North Sea to the Baltic Sea (Major Baltic inflows, MBIs) which can be monitored far into the deep Baltic Proper and which play an important role in controlling oxygen conditions in the deep Baltic (e.g. Matthäus and Franck 1992; Meier et al. 2018b).

The North Sea is a semi-enclosed basin located on the northwest European Shelf adjacent to the northeast Atlantic. The average depth is about $95 \mathrm{~m}$ and deepens towards the boundary to the North Atlantic in the north. The model domain (Fig. 1) also comprises the eastern part of the English Channel up to $4^{\circ} \mathrm{W}$. The model has 

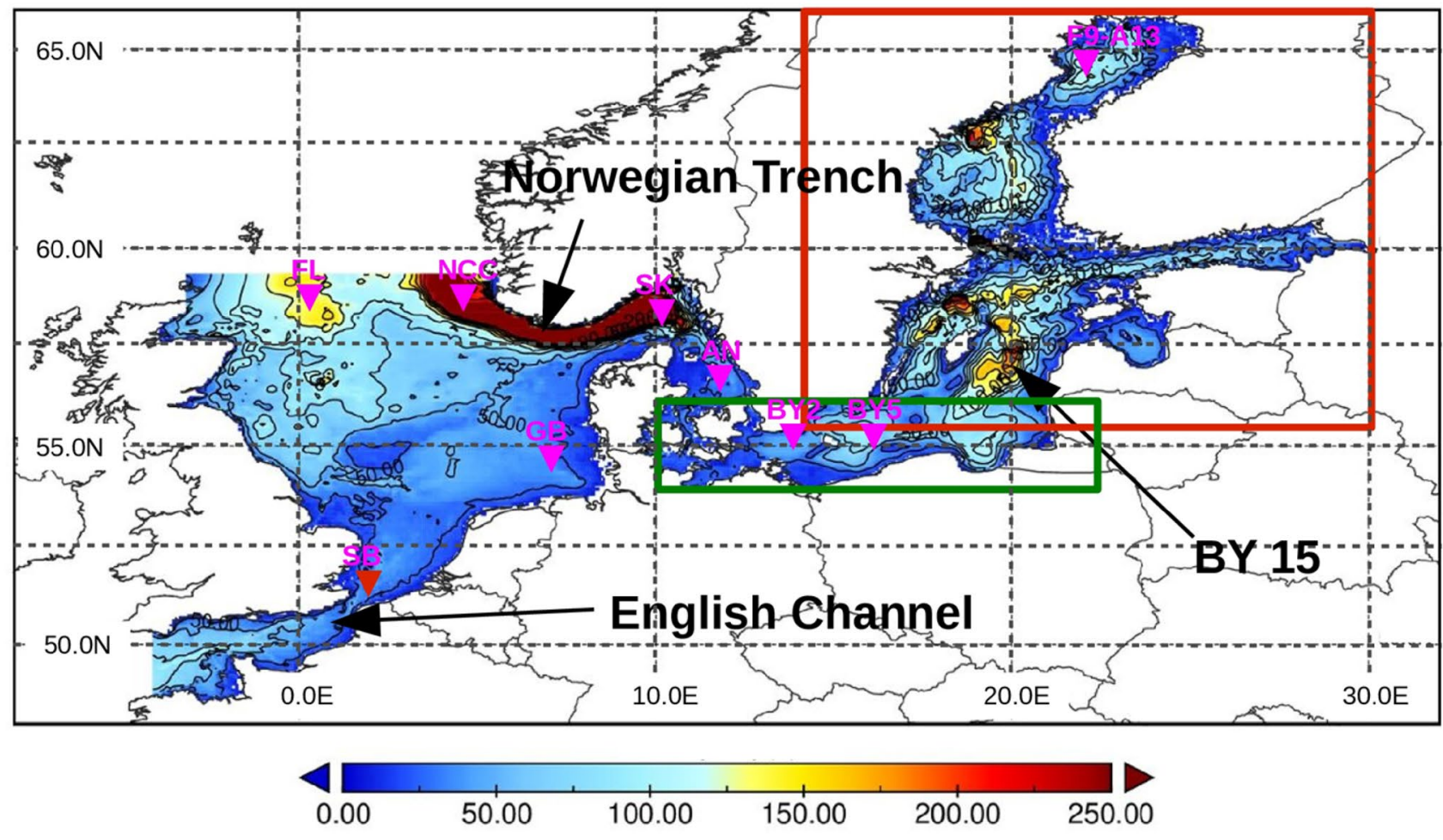

1 Kattegat

2 Great Belt + the Sound + Kiel Bay

3 Arkona Basin

4 Bornholm Basin

5 Eastern Baltic Proper + Gdansk Basin

6 Western Baltic Proper

7 Gulf of Riga

8 Gulf of Finland

9 Archipelago Sea

10 Åland Sea

11 Bothnian Sea

12 Bothnian Bay

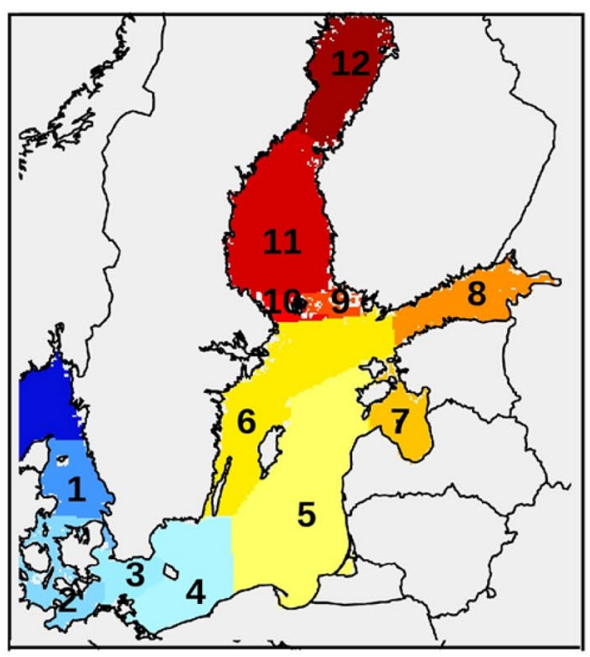

Norwegian Coastal Current, $S B$ Southern Bight, $G B$ German Bight, $S K$ Skagerrak, AN Anholt, BY2 Arkona Basin, BY5 Bornholm Basin, BY15 Baltic Proper, F9-A13 Bothnian Bay). Also shown is a division of sub-basins following Meier et al. (1999)

highest amplitudes along the inflow path of Atlantic waters east of Scotland and in the English Channel (Sein et al. 2015). The North Sea is seasonally stratified during summer when a strong thermocline develops in the northern, deeper part (e.g. Mathis and Pohlmann 2014). During the cold season nearly the entire North Sea (with the exception of the Norwegian trench) is well mixed. Due to this and the strong exchange with the North Atlantic the North Atlantic the North Sea is strongly influenced by tides with 
Sea has a flushing time in the order of 1 year (e.g. Hjøllo et al. 2009).

\subsection{Purpose of this study}

In this study we use the interactively coupled ocean-sea ice-atmosphere regional model RCA4-NEMO [Rossby Center Atmosphere model (Strandberg et al. 2014), Nucleus for European Modelling the Ocean, (Madec 2012) which is setup for the North Sea and Baltic Sea (Dieterich et al. 2019; Gröger et al. 2015; Wang et al. 2015)]. This model has been driven by the output from an ensemble of 15 different global climate simulations comprising the CMIP5 climate scenarios RCP2.6, RCP4.5, and RCP8.5. However, we here concentrate on the strongest warming scenarios following RCP8.5 which results in an ensemble of five scenarios mainly due to two reasons: (1) due to the large inertia of the water body the climate response of the ocean is relatively slow compared to land climate. Hence, on medium range time scales the ocean can be considered to respond more or less linear (with the exception of local sea-ice feedbacks) to external forcing which results in a qualitatively coherent ocean response to different climate scenarios. Thus, we here consider only the strongest RCP8.5 scenario where the responses can be best studied. (2) Furthermore, we do not investigate the aspect of uncertainty associated with the choice of different global models and different scenarios which has been done elsewhere (e.g. Meier 2015; Schrum et al. 2016; Meier et al. 2018a). We here focus on processes, i.e. we aim to identify and analyze coherent and incoherent responses across the ensemble and identify the responsible processes.

Thematically, we here concentrate primarily on the summer hydrographic conditions which are likely to influence the marine biology and biogeochemistry (Pätsch et al. 2017). Previous studies have often discussed the vertical stratification of the water column and its potential influence on biogeochemistry in both global (Steinacher et al. 2010; Bopp et al. 2013) and regional climate changes studies (Holt et al. 2012; Meier et al. 2012a; Bopp et al. 2013; Gröger et al. 2013; Mathis and Pohlmann 2014; Tinker et al. 2016; Saraiva et al. 2018). However, in regional ocean modeling studies stratification has been inferred mostly from temperature and/or salinity profiles at single stations while basin wide investigations are still rare (e.g. Holt et al. 2010; Väli et al. 2013; Mathis and Pohlmann 2014; van Leeuwen et al. 2015; Tinker et al. 2016). Therefore, in order to asses stratification, we here calculate pycnocline characteristics in terms of the highest density gradient in the water column and the depth of the pycnocline for every grid point of our ocean model. We further aim to distinguish the individual effect of salinity and temperature changes on the response of the pycnocline to climate warming.
In Sect. 2, we briefly introduce the coupled ocean-sea ice-atmosphere model RCA4-NEMO and the study area and provide a profound validation for present day climate. In Sect. 3, general results of changes in basic atmospheric and oceanographic variables between 1970-1999 and 2070-2099 are described and in Sect. 4 implications for plausible consequences on biogeochemistry and higher trophic species are discussed.

\section{The coupled ocean-sea ice-atmosphere model RCA4-NEMO}

\subsection{Model description}

The regional climate model (RCM) used here is fully described and comprehensively validated in Dieterich et al. (2019), so only a brief description with main characteristics is provided. Furthermore, the focus of this study is primarily on the ocean, so atmospheric variables are considered only so far as it is important for the interpretation of oceanic processes.

The coupled model consists of the atmosphere component RCA4 (Strandberg et al. 2014) with a resolution of $0.22^{\circ}$ $(\sim 24 \mathrm{~km})$. The regional model RCA4 is setup for the EUROCORDEX domain and along the open boundaries tracer and momentum from a global circulation model (GCM) are applied every $6 \mathrm{~h}$. The global model can either be a reanalysis like ERA40 or one of the scenarios from CMIP5 climate scenario suite (Taylor et al. 2012). The ice-ocean component in the RCM is based on NEMO 3.3-LIM3 (Madec 2011; Vancoppenolle et al. 2009). This model resolves the North Sea and the Baltic Sea at 2 nautical miles $(\sim 3.7 \mathrm{~km})$ and uses 56 vertical levels with a resolution of $3 \mathrm{~m}$ at the surface, increasing to $9 \mathrm{~m}$ in $100 \mathrm{~m}$ and to a maximum of $22 \mathrm{~m}$ at $711 \mathrm{~m}$. The regional ocean model has two open boundaries, one in the English Channel and another one in the northern North Sea. At those boundaries tracers and sea surface height (SSH) in monthly resolution are prescribed from a GCM. For the hindcast runs the ORAS4 reanalysis Balmaseda et al. (2013) provides the boundary conditions. For the climate scenario runs analyzed in this study the boundary conditions are taken from the ocean component that is part of the coupled global earth system model.

This strategy was chosen to ensure that climate induced changes in the North Atlantic are accounted for in our simulations as we think this is especially important for marginal seas with rapid flushing times like the North Sea (in the order of 1-2 years). Furthermore, the North Atlantic Sector has been identified to be very sensitive to climate change (e.g. Hand et al. 2018). During the historical period all ensemble members showed the same cyclonic 
circulation as this is shown for the hindcast case in the validation (e.g. Fig. 4a, Supplementary Material S1).

However, sensitivity studies under hindcast conditions showed that besides lateral boundary conditions for temperature, salinity, and SSH as used in this study, on-shelf barotropic transports prescribed at the lateral boundary yield a more vigorous and realistic circulation in the northern North Sea. Without that, inflow of Atlantic water turned out to be too weak which resulted in a barotropic streamfunction of only $0.6 \mathrm{~Sv}$ whereas most models indicate a circulation of around $1 \mathrm{~Sv}$ (e.g. Pätsch et al. 2017). In contrast to the northern boundary, the transports through the English Channel into the North Sea amount to $0.16 \mathrm{~Sv}$ which is in accordance with observations (0.14 Sv, Pätsch et al. 2017). Likewise, the cyclonic gyre circulation in the Skagerrak and the net Baltic inflow into the North Sea compare well with other established models (Suppl. Material; Pätsch et al. 2017). However, due to the above described deficiency at the northern boundary we decided to set the main focus of the study on the Baltic Sea, Kattegat, and Skagerrak region and not include barotropic transports at the northern boundary. This was done mainly due to two reasons: (1) validation of temperature and salinity yielded quite good results for the North Sea (see Supplementary Material S1). (2) From a more practical point of view, to obtain appropriate boundary conditions at the northern boundary would have required to generate circulation fields out of a model setup with an extended model domain covering also parts of the North Atlantic. This supports earlier findings by Mathis and Pohlman (2014) who used a larger domain covering the entire NW European shelf to obtain a realistic circulation in their North Sea model and to carry out one single climate projection. However, given the long time interval to simulate 140 years for each of the ensemble members, in this study the required computational effort was beyond available resources.

In addition to the prescription of global model output at the lateral boundaries, 11 tidal constituents are prescribed at the open boundaries taken from the tidal model by Egbert et al. (2010). Atmospheric information at the lateral boundaries of the atmosphere model RCA4 are likewise taken from global climate models (Dieterich et al. 2019).

The atmosphere and the ice-ocean components of NEMO-Nordic are coupled every $3 \mathrm{~h}$ using the OASIS3 coupler (Valcke 2013). The atmosphere receives ice and sea surface temperatures and the ice fraction and ice albedo. The ice-ocean component receives the vertical components of fluxes of heat, mass and horizontal momentum plus the sea level pressure. Further details of the coupling procedure are described in Gröger et al. (2015)

\subsection{Validation of present day climate}

The main validation of the ocean component of the coupled model is provided in the Supplementary Material S1 to this paper. In particular, we have tested the models skills to reproduce water temperatures and salinity using observations from in situ measurements at different stations indicated in Fig. 1 as well as satellite derived estimations for SST from the Federal Maritime and Hydrographic Agency, Hamburg, Germany. We further analyzed the skills of the model to reproduce mean circulation and water stratification. However, as demonstrated by Notz (2015), for climate purposes the model skills to reproduce observational climatologies is not the only factor to judge the usefulness of a model. Instead the models ability to reproduce variability and observed temporal changes are of particular importance for climate change studies. This applies even more when validating interactively coupled models as applied in this study. Thus, the validation is done mainly with respect to future climate applications i.e. the models skills are tested to reproduce mean climate and variability as well as interannual variations and the seasonal cycle. We here summarize these results and refer to the Supplementary Material S1 for a comprehensive validation.

The general cyclonic circulation pattern in the North Sea characterized by inflow at the northwestern boundary and through the English Channel and outflow at the northeastern boundary can be recognized (Fig. 4 in S1). Although the exchange with the Atlantic is underestimated by about $50 \%$ as mentioned above, salinity gradients in the North Sea are reproduced quite well. Comparison with stations of in situ data (see Fig. 1 for station positions) reveals that varying different hydrographic conditions in the North Sea like the stratified Norwegian Coastal Current (NCC), open ocean conditions at Fladden Ground as well as in shallow southern well mixed environments are reproduced. Especially the dynamics of the seasonal thermocline (Figs. 2 and 5 in S1) are simulated. However, a too weak water exchange with the North Atlantic explains too low salinities in the northernmost North Sea. Like for most North Sea models the strongest biases in salinity and temperature occur in coastal regions mainly due to too low vertical resolution and insufficient meteorological forcing (see Pätsch et al. 2017, for a detailed discussion on that issue). Most important for climate studies however, the interannual variability is well correlated with observations from both satellite derived SST, as well as in situ measurements for water temperature and salinity from the Climate Water Navigation (KLIWAS) data set (Bersch et al. 2013).

In the Baltic Sea, the model captures the different hydrographic settings from the transition from the North Sea (Skagerrak, Kattegat, BY2) zone to the Baltic Proper (BY15) and finally to the Bay of Bothnia (F9-A13). Especially the 
seasonal dynamics of thermal stratification is well reproduced. Generally too low salinities are found in the deeper parts of the Baltic Sea. Thus, the haline stratification is somewhat too weak in the Baltic Sea. Comparison with satellite derived products from the $\mathrm{BSH}$ reveals that interannual variations of SST are well reproduced. This is likewise true for the models ability to reproduce interannual variations of the annual maximum sea ice extension as revealed by comparison with satellite derived data from the SMHI (Fig. 8 in S1).

Finally, comparison with compiled data sets from the World Ocean Atlas reveals that the seasonal cycle of stratification as indicated by the potential density anomaly is well captured by the model in both the North Sea and the Baltic Sea (Fig. 7 in S1).

Besides the main validation provided in the Supplementary Material S1 the ocean component was validated and compared with other models (Pätsch et al. 2017). Pätsch et al. (2017) tested in particular the models ability to reliably simulate the hydrographic variables in the North Sea relevant for ecosystem simulations. The authors showed that the model used in this study lies well within the spread of other established North Sea models and compares well with observations. In addition, with focus on the atmospheric part of the model, Wang et al. (2015) showed that the model simulates the present day climate realistically enough to be applied in climate scenarios.

\subsection{Experimental setup}

The global climate scenarios are taken from five global climate scenarios based of the CMIP5 models MPI-ESM-LR (MPIESM in the following), HadGEM2-ES (HadGCM), EC-EARTH, GFDL-ESM2 M (GFDL), IPSL-CM5A-MR (IPSL). These global scenario simulations were downscaled with the high-resolution ocean-sea ice-atmosphere model RCA4-NEMO. Both RCA4 and NEMO needed global model data which were interpolated onto the lateral boundaries of the regional models. At the lateral boundaries of the regional model, necessary forcing fields from the global model were interpolated onto the grid of the respective regional component of RCA4-NEMO. The model simulations were carried out for the historical period from 1961 to 2005, and for the corresponding RCP8.5 scenarios from 2006 to 2100 provided by the global models. Although RCA4-NEMO contains a river routing scheme that allows to diagnose the runoff to the sea from the global scenario simulations this was not applied here because also only small biases in atmospheric precipitation and evaporation fields over the huge drainage basin would accumulate into too strong biases in runoff. Instead, the runoff was taken from the hydrological model E-HYPE (Donnelly et al. 2016) that was driven by the ERA interim reanalysis data set for the historical period between 1979 and 2008 (between 1961 and
1978 a daily climatology was used). For the future period an increase was assumed in the order of $10 \%$ from 2006 for the Bothnian Sea and Bothnian Bay until 2100. This average value stems from calculations by Meier et al. (2012b) and Saraiva et al. (2018) who analyzed the impact of climate change in different climate scenarios from the hydrological model E-HYPE. Likewise, previous calculations support this number (Meier et al. 2012b).

The main focus of this study is on climate driven changes in the summer hydrography with relevance for ecosystems. However, where necessary for the interpretation of the results winter and/or annual mean hydrographic changes are included in the analysis.

\section{Results}

\subsection{Hydrographic changes and changes in large-scale circulation of the Baltic Sea}

\subsubsection{Atmospheric response and changes in the Skagerrak hydrography}

Figure 2 shows the general response of SST and sea surface salinity (SSS) to the different RCP8.5 scenarios averaged over the Baltic Sea. All ensemble members consistently show a freshening. Furthermore, the whole model domain including the North Sea (not shown) is affected by the freshening. This result supports previous results from climate downscaling experiments for the Baltic Sea and the North Sea as well (e.g. Holt et al. 2010, 2012; Meier et al. 2011; Tian et al. 2013; Gröger et al. 2013; Mathis and Pohlmann 2014; Meier 2015; Tinker et al. 2016; Schrum et al. 2016, Saraiva et al. 2018; Meier and Saraiva 2019) which all report a freshening of the North Sea independent of the applied scenario. The freshening mainly reflects the well-known phenomenon of an intensified water cycle seen in global climate scenarios which leads to stronger moisture convergence and increased net precipitation in mid to high latitude regions while subtropical regions become dryer (e.g. Lau et al. 2013; Collins et al. 2013; Levang and Schmitt 2015). In agreement with this, our downscalings consistently show a characteristic north-south pattern with increased summer precipitation in the north and lowered precipitation over continental central Europe at the end of the twenty-first century (Fig. 3a). Moreover, this pattern is in all realizations associated with stronger wind speeds over the Atlantic and the westerlies are likewise shifted/extended further to the north during the warm season (Fig. 3b, c). However, the dryer conditions during summer over wide areas of the southern North Sea and Central Europe (e.g. EC-Earth and HadGCM) are compensated for by considerably wetter conditions during winter (not shown here) which leads to a freshwater surplus 

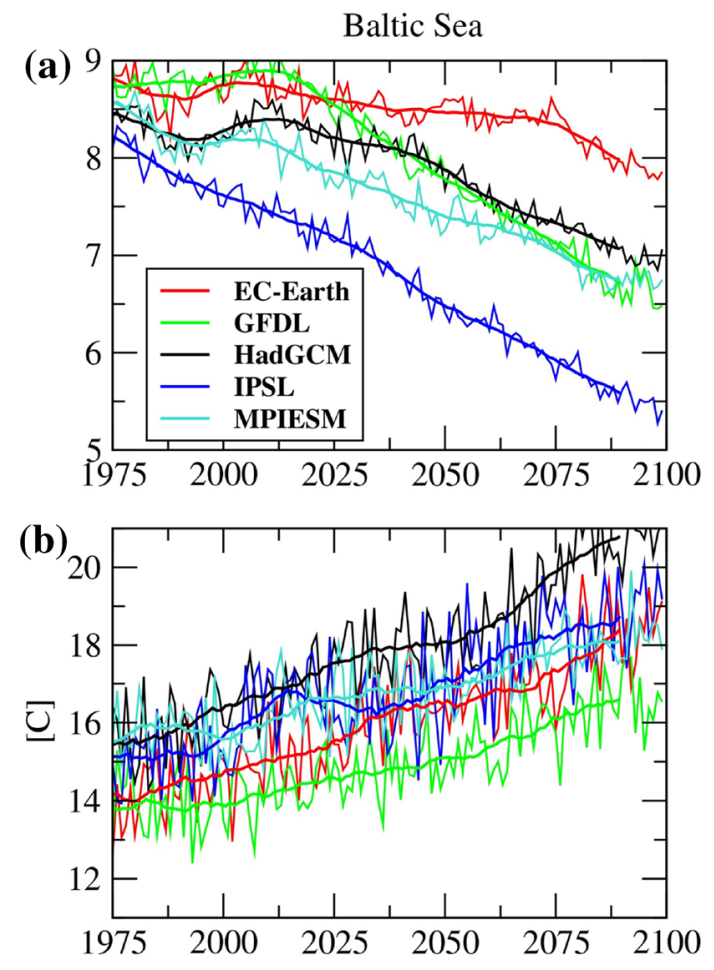

Fig. 2 Time series of $\mathbf{a}$ sea surface salinity and $\mathbf{b}$ sea surface temperature averaged over the Baltic Sea. Shown is the average over months June, July and August. Thick lines indicate the 20-year running mean. The results are from the high resolution regional ocean model NEMO

in the annual mean at the end of the twenty-first century. Hence, SSS (also during summer) are reduced.

Regional salinity changes are dominated by a characteristic and consistent pattern in the Skagerrak in all simulations (Fig. 4). Hence, very strong freshening is seen in the southern Skagerrak while in the northern Skagerrak freshening is only weak. This pronounced small-scale pattern is mainly linked to local changes in the surface circulation.

In the Skagerrak, the cyclonic circulation is enhanced as indicated by stronger velocities in the Danish and Norwegian part of the Skagerrak (Fig. 5). As a result, more freshwater from the Baltic recirculates and causes a strong negative salinity anomaly in the southern Skagerrak while along the Norwegian coast of the Skagerrak the overall freshening is damped by surplus of higher saline water from the southern Skagerrak originating from the North Sea. The main driver of these changes is an altered wind field at the end of the twenty-first century compared to the twentieth century. Figure 3 shows that most pronounced wind changes occur over the Skagerrak region. Wind flow at $10 \mathrm{~m}$ is consistently strengthened across the realizations. The stronger winds stimulate the cyclonic water circulation in the region.

Also the predominant wind direction is important in this concern. In a recent study, Christensen et al. (2018) could show that a $\mathrm{NE}$ wind regime tends to facilitate the freshwater export out of the Baltic. Indeed, we found in four out of five ensemble members a strong decline in NE wind occurrences (between -13.6 and $-27 \%$ ) at the end of the twenty-first century compared to end of the twentieth century. Likewise, SW winds increased between 7.3 and $22.0 \%$ in three ensemble members. Thus the change in wind direction over the Skagerrak region supports longer residence times of freshwater in this region.

\subsubsection{Baltic Sea}

In the Baltic Sea the projected changes in SSS show a more homogeneous pattern of freshening without dominant small-scale features as described for the North Sea (Fig. 4). Overall, the basin averaged SSSs (Fig. 2, Table 1) decrease between $\sim 0.6$ (EC-Earth) and $2.3 \mathrm{~g} \mathrm{~kg}^{-1}$ (IPSL). On longer time scales the salinity in the Baltic Sea may also be influenced by changes in the dynamics of the well-known sporadic inflows of salt rich waters from the North Sea near the bottom. A general definition or unambiguous detection method for the inflow of salt rich water into the Baltic Sea is still lacking. Methods based on observational evidence at specific geographic sites are problematic as discussed in Mohrholz (2018). Moreover, methods working under present day hydrographic conditions will not necessarily work reliably under future conditions, which are likely to undergo considerable alteration in the course of climate change.

To assess the aforementioned general and basin integrated effect of stronger winds on the Baltic Sea circulation we calculated the meridional overturning circulation following the approach of Döös et al. (2004). This method integrates the meridional velocity components both over depths and from east to west over a wider region (red rectangle in Fig. 1). It is therefore less sensitive to changes in local hydrographic conditions and therefore monitors the large-scale circulation in the Baltic Sea more robustly than times series from specific stations. Figure 6 a shows the ensemble mean of the meridional overturning circulation from about $56^{\circ} \mathrm{N}-66^{\circ} \mathrm{N}$. The average over the period 1970-1999 shows three main circulation cells from south to north: the main cell located in the southern Baltic Proper up to $58^{\circ} \mathrm{N}$ (R1 and R2 in Fig. 6a) is mainly thermohaline driven at depth. The lower limb of this cell largely reflects the flow path of salty water from the North Sea through the Baltic Sea. A second shallower cell is seen in the northern part of the Baltic Proper $\left(\sim 58.7^{\circ}\right.$ to $\left.\sim 60^{\circ} \mathrm{N}\right)$. Further to the north lies the small but nevertheless very deep cell of the Aland Deep $\left(\mathrm{R} 3,60^{\circ} \mathrm{N}\right)$. The northernmost cells reflect the circulation within the Bothnian Sea (R4) and the Bothnian Bay (not marked in Fig. 6a).

The ensemble average over the period 2070-2099 shows an overall moderate weaker overturning (Fig. 6a) in most cells. However, this result is not consistent across all the individual ensemble members. In order to study the temporal evolution of overturning for specific basins we follow earlier 
(a)
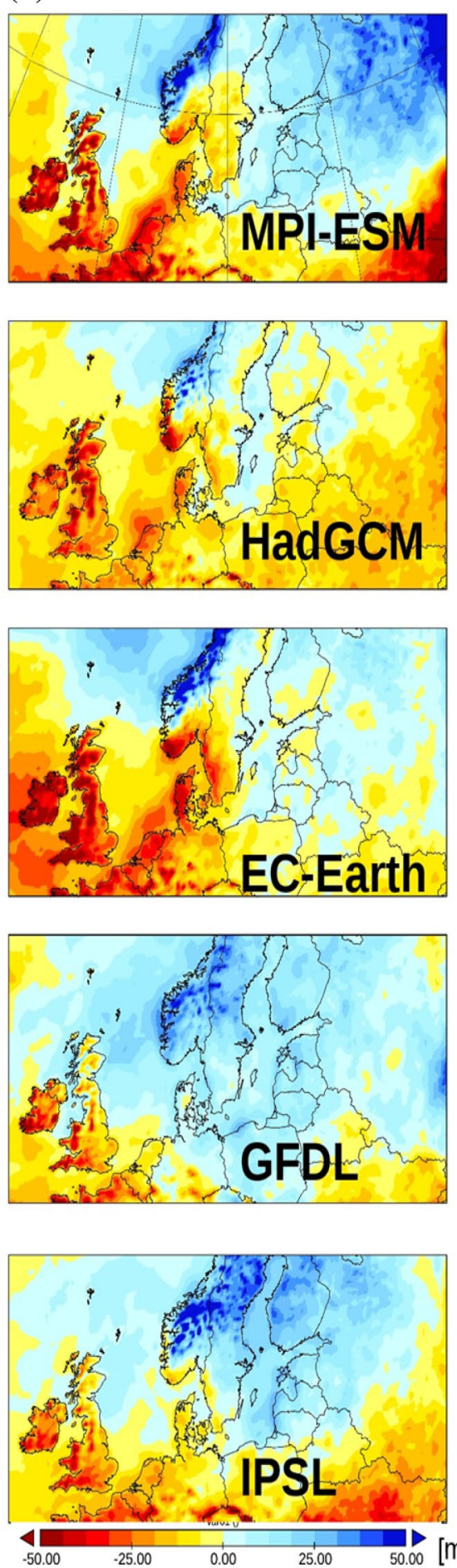

(b)
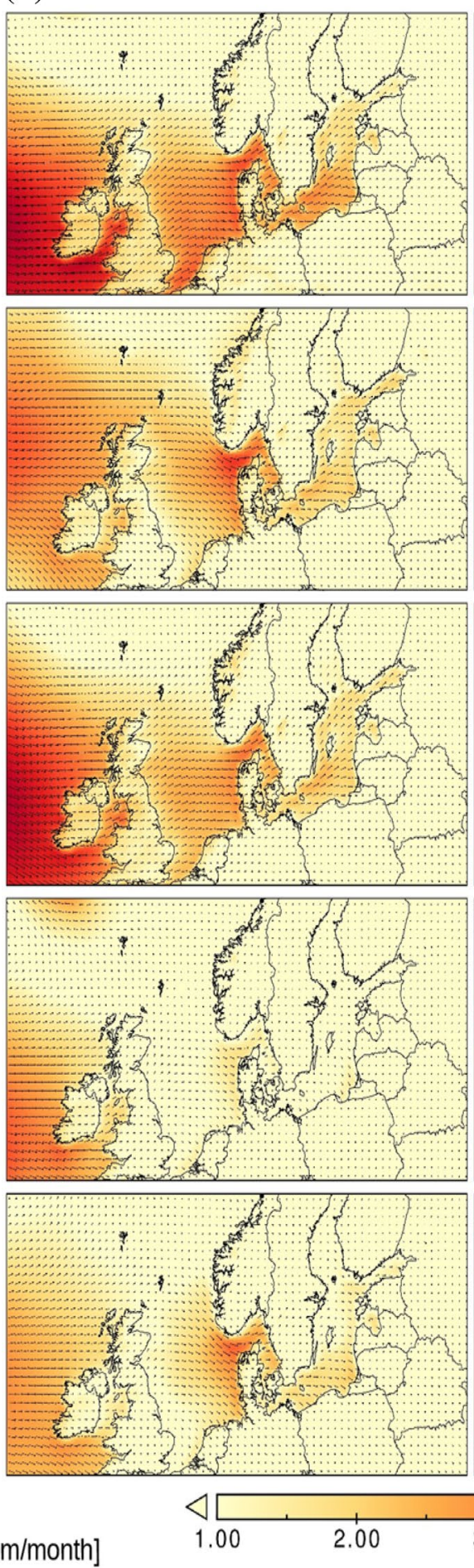

(c)
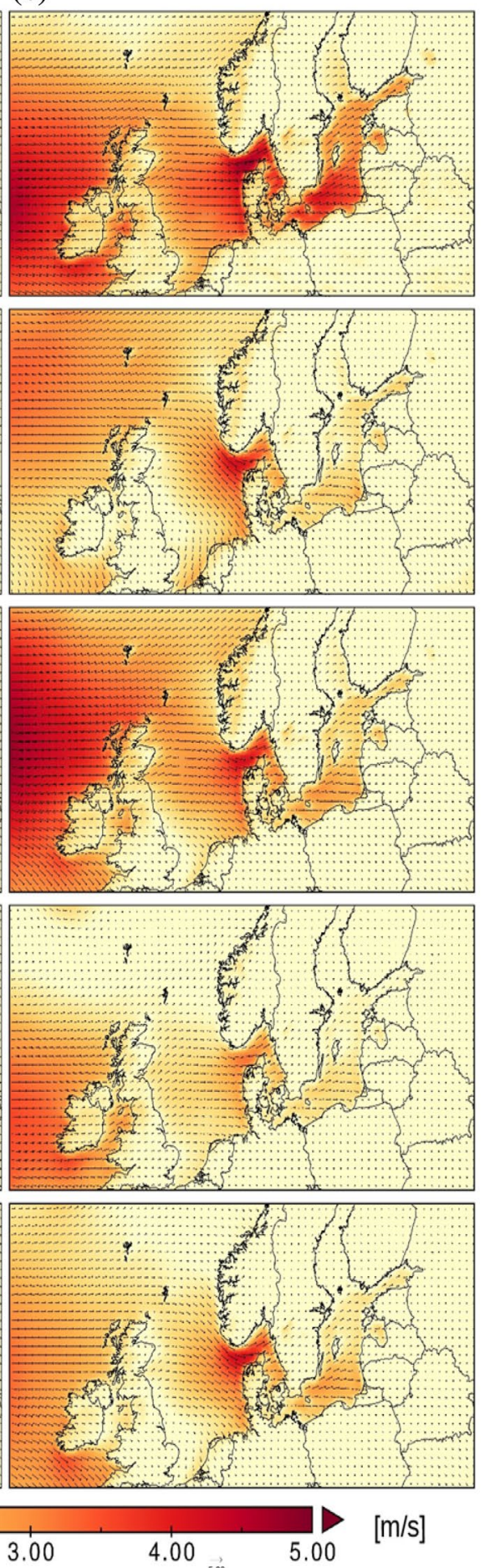

Fig. 3 Left: a Difference precipitation (2070-2099 minus 1970-1999). b Average summer (1970-1999) 10 m wind field. Color bar indicates wind speed. c Same as b but for average summer (2070-2099)

approaches and extracted the maximum value of overturning along the depth axis at key positions along the latitudinal axis (see e.g. Mikolajewicz et al. 2007). Figure 6b shows the time series of maximum overturning for the main cell in the southern Baltic Proper between $54.5^{\circ} \mathrm{N}$ and $57.5^{\circ} \mathrm{N}$ (R1). Hence, the total overturning within this cell shows no significant trend throughout the twenty-first century. However, in two realizations the northern extension of this cell (R2 in 

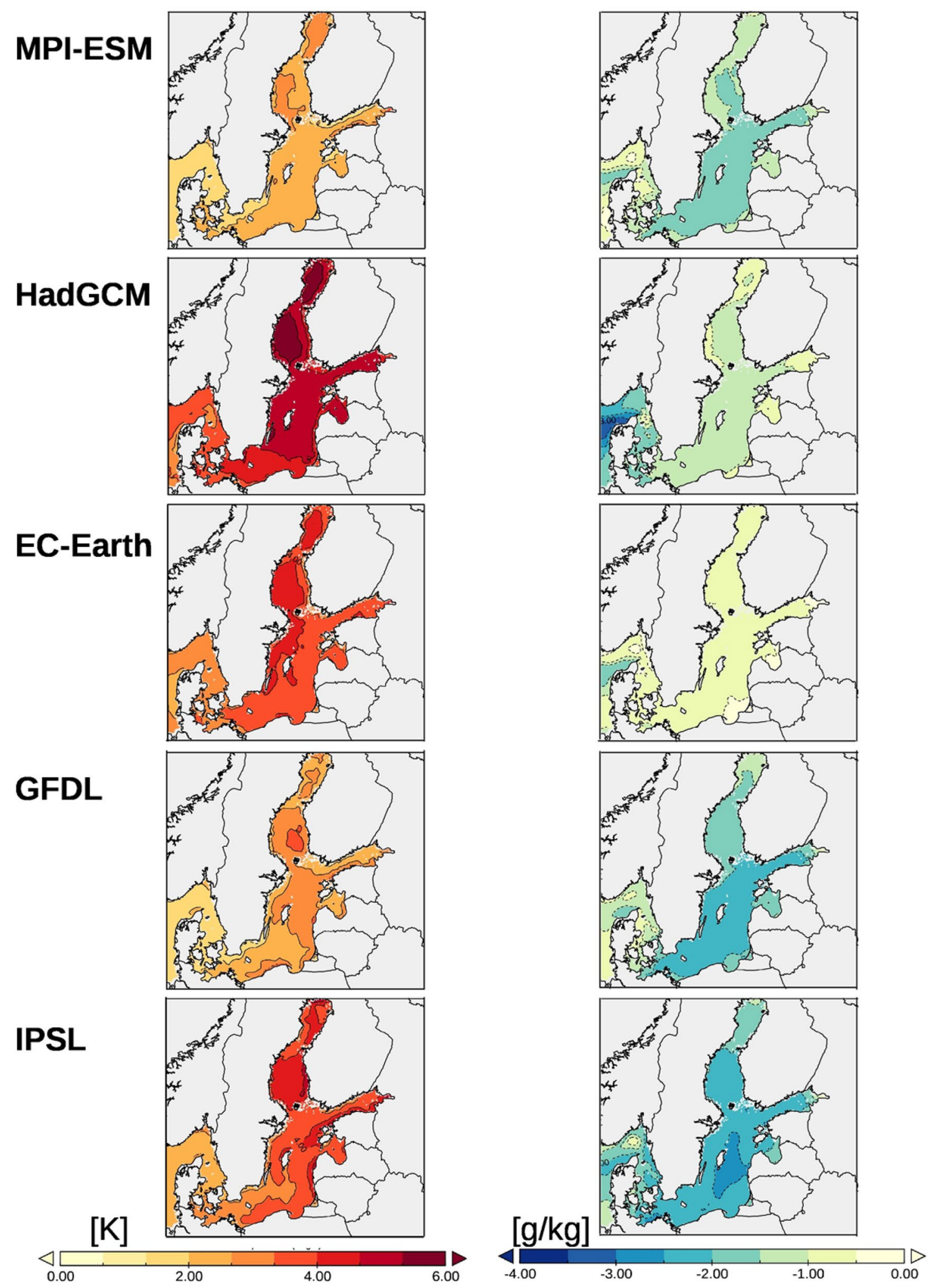

Fig. 4 Difference in average summer climatology (2070-2099 minus 1970-1999). Left: sea surface temperature. Right: sea surface salinity 


\section{Surface circulation Skagerrak}

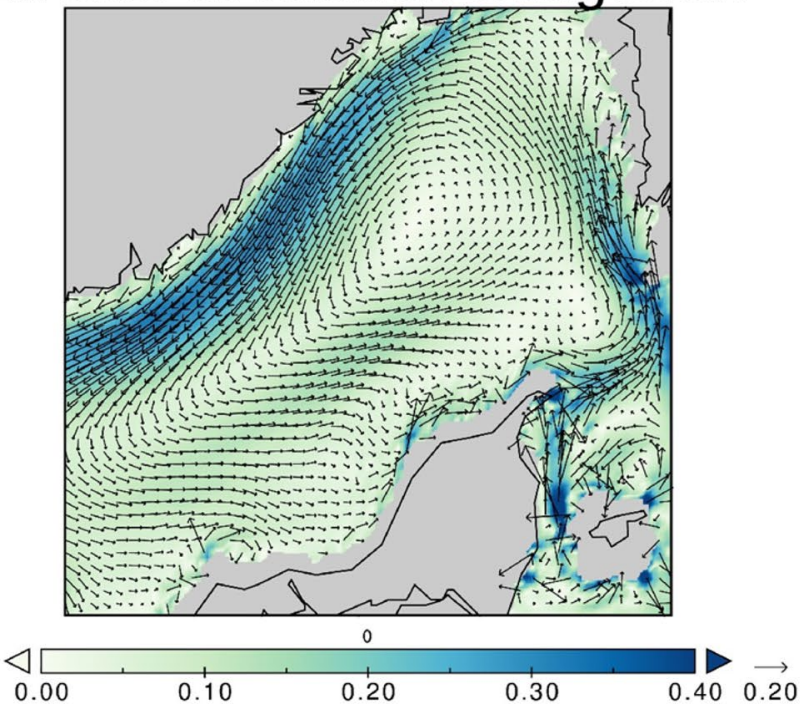

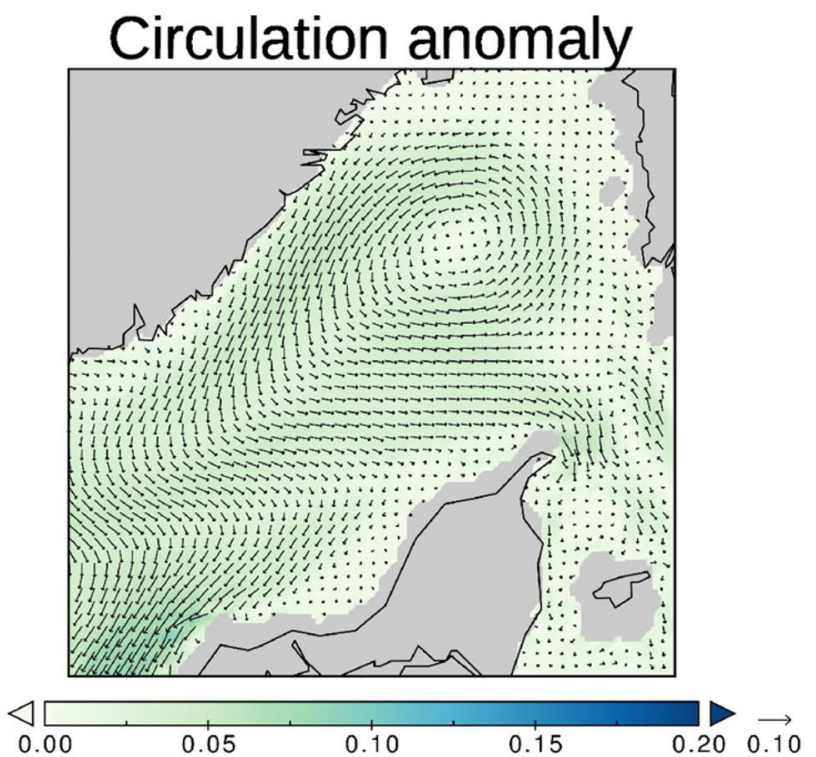

Fig. 5 Left: average summer circulation for the Skagerrak (1970-1999). Right: difference (2070-2099 minus 1970-1999). The colour bar indicates current speeds. Shown is the ensemble mean. Note the different scaling of the colour bar and the different scale of the reference vector

Fig. 6a, c) shows significant decreases of $\sim 30 \%$ (GFDL) and $50 \%$ (IPSL). In these realizations the cells extend less far to the north in a warmer climate at the end of the simulations.

Despite this different behavior in large-scale circulation in the Baltic Proper across the ensemble members, the response in deep salinity is at least in qualitative agreement across the simulation. Station BY15 (Fig. 1) in the Gotland Basin is often taken to monitor MBIs further downstream from the overflow area in the Kattegat. The simulated salinity time series at $\sim 200 \mathrm{~m}$ depth consistently shows negative trends in all realizations towards the end of the century (Fig. 7). Differences are however, seen in the magnitude and timing of salinity reductions. While IPSL shows a strong negative trend over the whole period, GFDL and HadGCM start to decrease around the middle of the century. MPIESM starts a bit earlier but exhibits large amplitude fluctuations along the whole record (Fig. 7). These characteristics can be well

Table 1 Climate change (2070-2099 minus 1970-1999) response of the Baltic Sea calculated for different environmental parameters

\begin{tabular}{llllll}
\hline & MPI-ESM & HadGCM & EC-Earth & GFDL & IPSL \\
\hline$\Delta$ SST (K) & +2.27 & +4.67 & +3.70 & +2.50 & +3.52 \\
$\Delta$ SSS $\left(\mathrm{g} \mathrm{kg}^{-1}\right)$ & -1.47 & -1.0 & -0.59 & -1.90 & -2.27 \\
$\begin{array}{l}\text { Pycnocline inten- } \\
\quad \text { sity (\%) }\end{array}$ & +9.5 & +35 & +25 & +15 & +21 \\
Stratified area (\%) & +23 & +78 & +100 & +36 & +53
\end{tabular}

$\triangle S S S$ sea surface salinity, $\Delta S S T$ sea surface temperature, pycnocline intensity change in pycnocline intensity based on the largest density gradient in the water column, stratified area change in area with a pycnocline intensity larger than $0.05 \mathrm{~kg} \mathrm{~m}^{-3} \mathrm{~m}^{-1}$ recognized in the area averaged SSSs (Fig. 2). Also here (Fig. 7), IPSL shows a strong decreasing trend right from the beginning while MPIESM, EC-Earth and HadGCM decline later. The magnitude of salinity reductions seen at BY15 is about the same as at the surface in Fig. 2 (EC-Earth weakest, IPSL strongest). By contrast, the temporal evolution of large-scale circulation inferred from the overturning circulation times series (Fig. 6b, c) is uncorrelated to the deep salinity trends (Fig. 7).

In order to test if the altered salinities of intruding waters take influence on the salinity trends seen at BY15 we analyzed bottom salinities at different stations in the Skagerrak. However, the changes between 1970-1999 average and 2070-2099 average indeed indicate a freshening of the deep Skagerrak but the changes very small ( -0.1 to $-0.9 \mathrm{~g} \mathrm{~kg}^{-1}$ ) and thus more than one order of magnitude lower than at BY15. Hence, it is very unlikely that lowered salinities of inflowing waters substantially contribute to the trends seen at station BY15 (Fig. 7) compared to the total freshwater surplus from river runoff and precipitation into the Baltic. However, as indicated by the declining overturning circulation in the northern part of the Baltic Proper (R2 in Fig. 6), salt inflows possibly proceed less far north into the Baltic at the end of the twenty-first century.

In order to briefly investigate the effect of changes in overflow closer to the core location of the dense salt inflows (Kattegat), we have calculated the overturning function along the zonal direction by integrating the u-velocity component between the southern Baltic coast and $56^{\circ} \mathrm{N}$ (green rectangle in Fig. 1). Two main circulation cells are seen in the ensemble mean displayed in Fig. 7b: an upper wind driven cell 

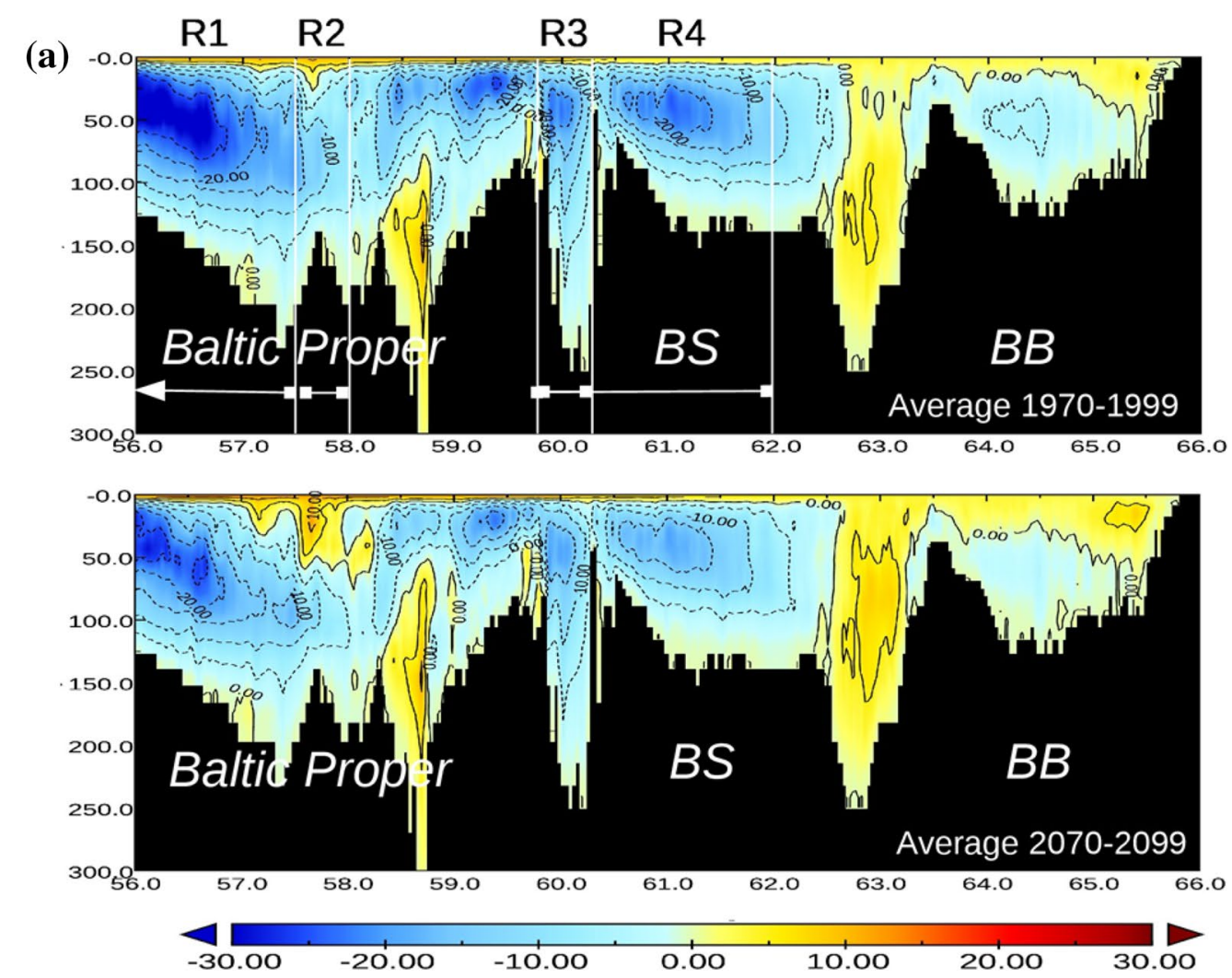

(b)

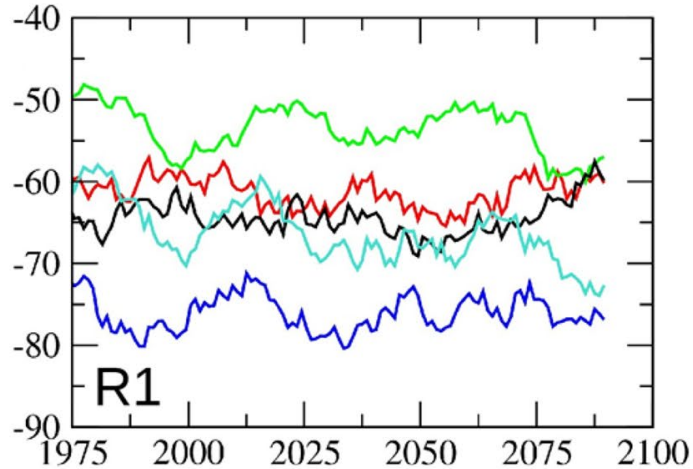

(d)

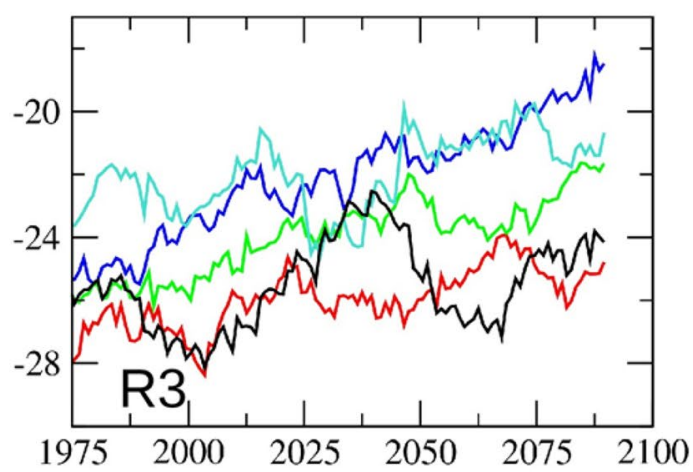

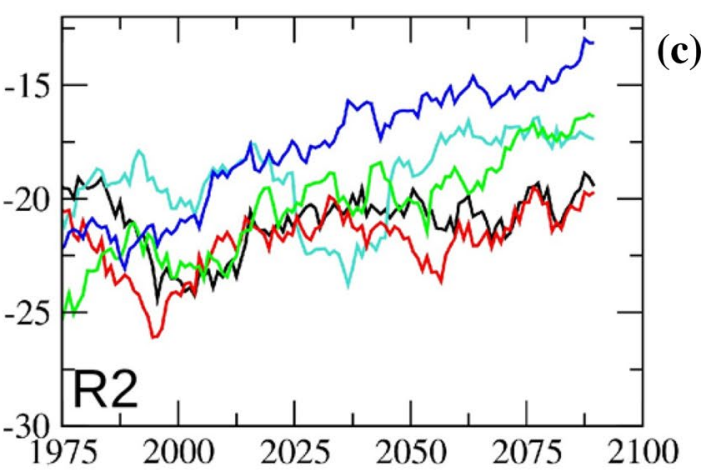

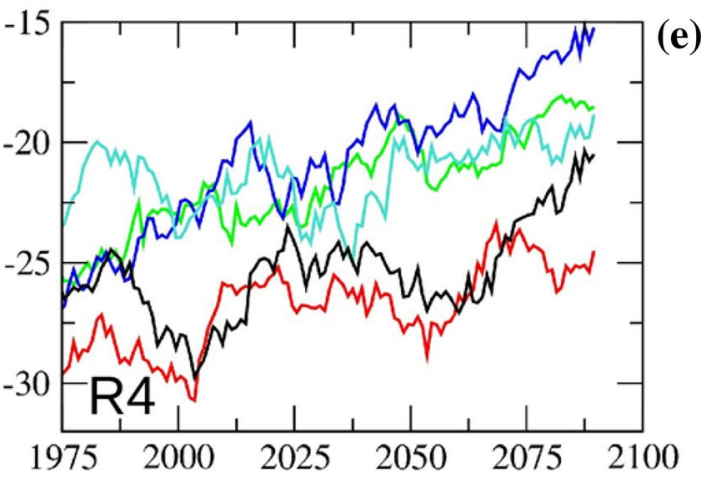

Fig. 6 a Ensemble average of meridional overturning circulation $\left(1000 \mathrm{~m}^{3} \mathrm{~s}^{-1}\right)$. $B S$ Bothnian Sea, $B B$ Bothnian Bay. Negative values indicate counter clockwise circulation. $\mathbf{b}$ Timeseries of max. overturnig circulation between $54.5^{\circ} \mathrm{N}$ and $57.5^{\circ} \mathrm{N}$. (R1) $\mathbf{c}$ same as $\mathbf{b}$ but between $57.5^{\circ} \mathrm{N}$ and $58.0^{\circ} \mathrm{N}$. (R2) d same as b but between $60.3^{\circ} \mathrm{N}$ (R3) and $62.0^{\circ} \mathrm{N}$. (R4) e same as b but between 59.8 and $60.3^{\circ} \mathrm{N}$ (R3). Shown are 20-year running averages. Color code is identical with Fig. 2 
Fig. 7 a Monthly mean salinity time series at BY $15\left(57.32^{\circ} \mathrm{N}\right.$; $\left.20.69^{\circ} \mathrm{E}\right)$. b Zonal overturning circulation $\left(1000 \mathrm{~m}^{3} \mathrm{~s}^{-1}\right)$ integrated over an area from the southern coast to $56^{\circ} \mathrm{N}$. Upper panel $=$ average $1970-1999$. Bottom panel $=$ average 2070 2099. Positive values indicate clockwise rotation

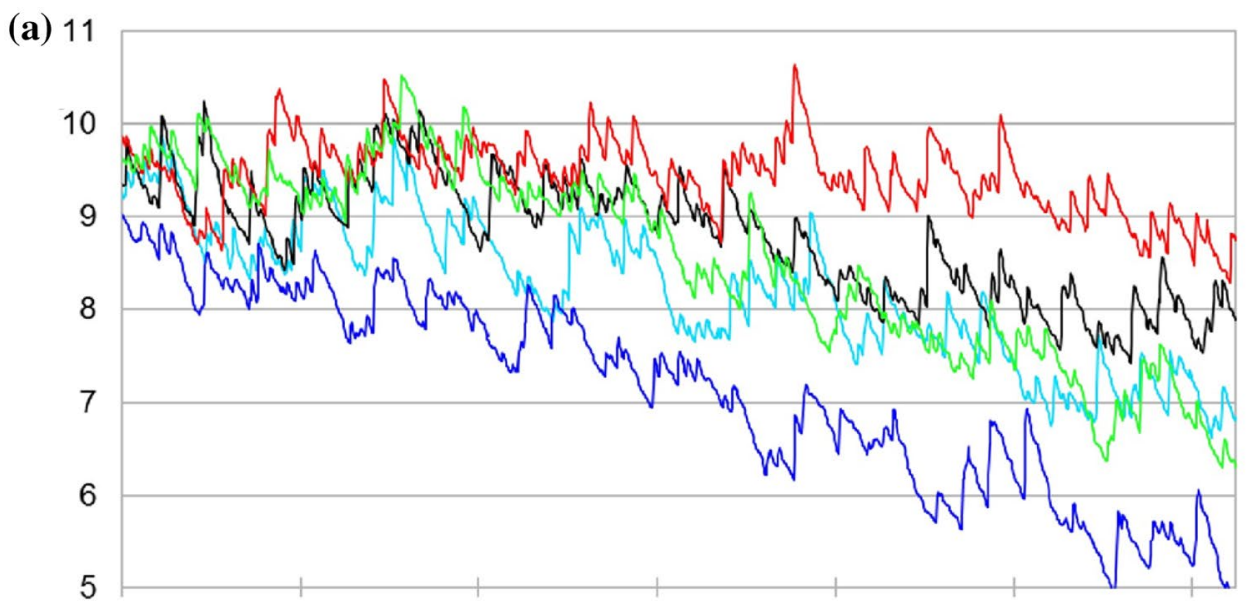

1975-01-16 1995-01-16 2015-01-16 2035-01-16 2055-01-16 2075-01-16 2095-01-16
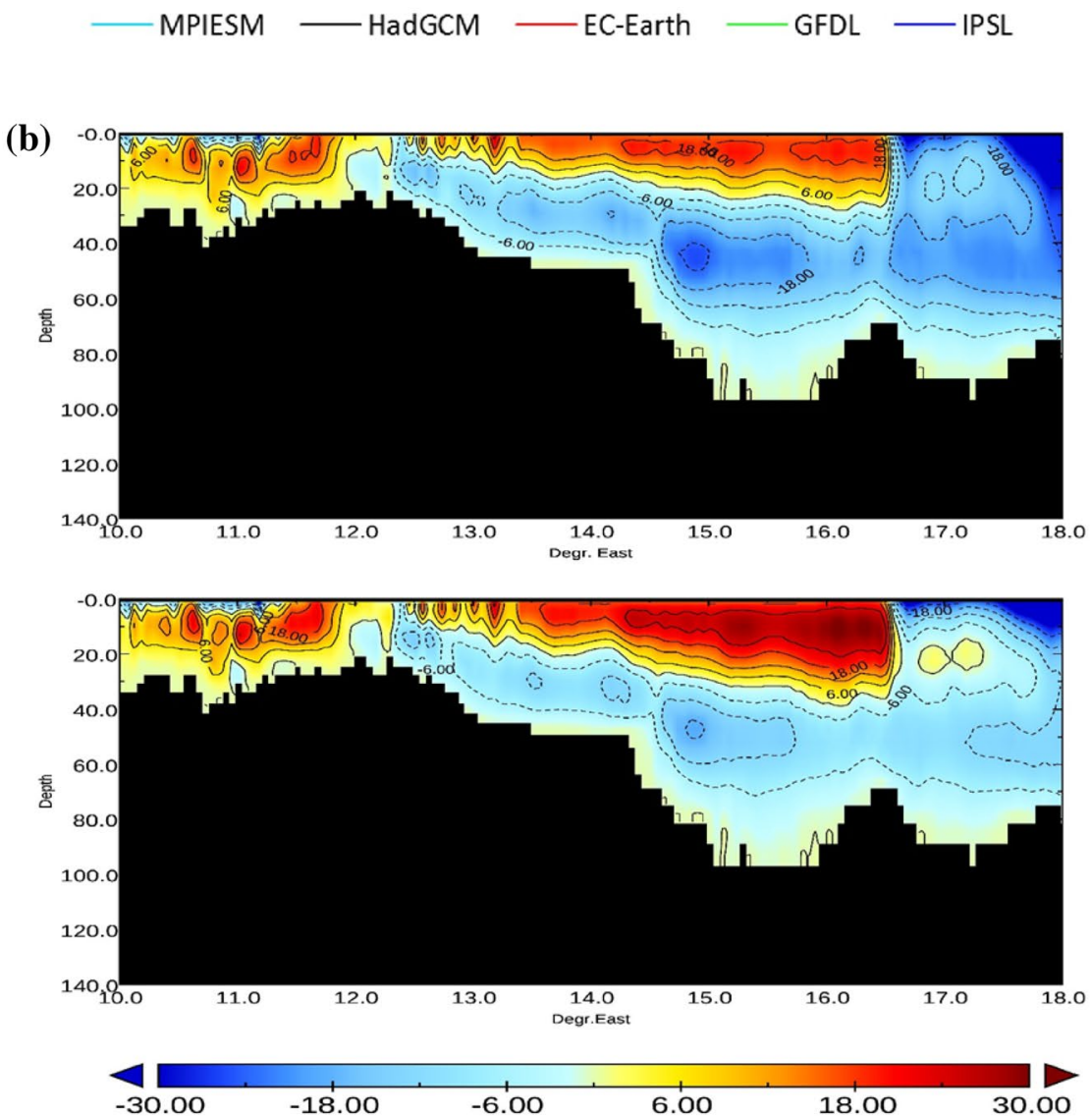

between $12.5^{\circ}$ and $16.5^{\circ} \mathrm{E}$ which transports saline surface waters to the East, and a lower cell which rotates anticlockwise indicating eastward transport of saline bottom waters. This lower cell is strongest at around $14.7^{\circ} \mathrm{E}$ at the transition from the Arkona to the Bornholm Sea. The effect of climate change is obvious from Fig. 7b. The wind driven upper cell has become substantially stronger at the end of the twenty-first century compared to the end of the twentieth century. Furthermore, the wind driven upper cell extents further to depth (max $30 \mathrm{~m}$ compared to max. $40 \mathrm{~m}$ at the eastern end of the cell). By contrast the lower thermohaline driven cell became substantially weaker. The maximum value of this cell located at around $15^{\circ} \mathrm{N}$ is reduced from 25.5 to $18.7 \times 10^{3} \mathrm{~m}^{3} \mathrm{~s}^{-1}$ or roughly $25 \%$. This suggests the circulation in the lower southern Baltic is much more sluggish while the circulation in the near surface layers is enhanced.

In the same way, we calculated the zonal overturning function to assess the integrated volume transports the 
mass salt transport was calculated by multiplying the salt concentration $\left(\mathrm{kg} \mathrm{ton}^{-1}\right)$ by the volume transports prior to integration. The overturning function then displays the overturning of salt (ton $\mathrm{s}^{-1}$ ). The resulting pattern (not shown) is nearly identical as for the volume overturning, showing the same main cells as seen in Fig. 7b. Here the maximal value in the lower cell at $14.7 \mathrm{~N}$ is reduced by $\sim 96$ tons s$^{-1}(=36 \%)$.

A consistent response in meridional overturning is seen in the Åland Deep (R3, Fig. 6d) and in the Bothnian Sea (R4 in Fig. 6e) where the overturning circulation decreases in nearly all ensemble members. Here, only the MPIESM realization shows no significant trend (although the overturning remains on a low level around $20,000 \mathrm{~m} \mathrm{~s}^{-1}$ from 2050 onward). A more step like increase is seen in EC-EARTH (red in Fig. 6d, e) with main steps around 2000 and 2050. HadGCM declines strongest during the last 30 years while IPSL and GFDL show a similar strong trend as described for the northern part of the Baltic Proper (R2).

\subsection{Sea surface temperature}

The simulated summer SSTs respond to the warming climate by an increase between $\sim 1.5 \mathrm{~K}$ (GFDL, MPIESM) and $\sim 3.5 \mathrm{~K}$ (HadGCM) in the North Sea and between 2.4 and $4.7 \mathrm{~K}$ in the Baltic Sea (Fig. 2, Table 1). A strong warming of the Baltic Sea is consistent among the models (Fig. 4). Weakest warming is seen in the Kattegat and Skagerrak region. Although, there is a substantial heat loss due to reduced sea ice thickness and sea ice extent during winter (not shown). However, this does not lead to notably weaker warming in the northern region (e.g. Bothnian Sea and Bothnian Bay) indicating a rather low thermal inertia of these regions.

\subsection{Stratification}

\subsubsection{General characteristics}

So far we have shown substantial warming and freshening of the Baltic Sea in our downscaling simulations. In the following, we aim to assess the resulting effect on the stratification of the water column. We will further discuss the individual effects of temperature and salinity change on the stratification and discuss the implication for process uncertainty in a broader context.

We here describe the stratification primarily by pycnocline characteristics during summer, i.e. the intensity of the pycnocline (expressed as largest density gradient in the water column), and the depth of the pycnocline. Figure $8 \mathrm{a}$ (left) shows the pycnocline depth for the historical period and the change at the end of the twenty-first century (Fig. 8a, right). Consistently across all models the pycnocline is deepest in the southern Baltic Sea (Arkona and Bornholm basins) in the historical period. The response to climate change (Fig. 8a, right) is rather inhomogeneous. Areas where at least the sign of change is more or less consistent are the southern Baltic and Skagerrak. In the northern Skagerrak the pycnocline slightly shallows while a deeper pycnocline is registered in the southern Skagerrak at the end of the twenty-first century. This pattern strongly is consistent with the changes described in salinity where strongest freshening is seen in the southern Skagerrak (Fig. 4). In the Baltic Sea the most areas south of the Bothnian Sea reflect a shallowing of the pycnocline. In particular, the regions south of Sweden, i.e. the Arkona Sea and the Bornholm Sea the pycnocline is substantially shallower at the end of the twenty-first century (Fig. 8a, right). In this area the pycnocline shallows by up to $27 \%$ in the ensemble mean.

A more consistent pattern is seen in the response of pycnocline intensity (Fig. 8b). Both the North Sea and the Baltic Sea show a widespread intensification of the pycnocline with maxima in the Kattegat/Skagerrak and the eastern North Sea. These regions belong to most intensely stratified areas (Fig. 8b, left) of the North Sea already during the historical period and the extension of these areas causes local maxima in the climate change signal (Fig. 8b, right). In the Baltic Sea the pycnocline intensification exhibits a more homogeneous and widespread pattern without local hot spots. However, the ensemble spread of intensification is rather large in the Baltic Sea. While in MPIESM the intensification is almost everywhere lower then $+0.03 \mathrm{~kg} \mathrm{~m}^{-3} \mathrm{~m}^{-1}$, in HadGCM most regions are above $+0.06 \mathrm{~kg} \mathrm{~m}^{-3} \mathrm{~m}^{-1}$.

In order to get insight into the large-scale temporal dynamics of highly stratified areas we calculated time series of area averaged pycnocline characteristics. Hence, we here only consider the area where the pycnocline intensity exceeds a certain threshold. We further note that the following discussion of summer pycnocline intensity and depth largely refers to changes in the thermal stratification while the halocline dynamics is of less importance (with the exception of the Kattegat and Skagerrak).

In order to classify different areas of stratification van Leeuwen et al. (2015) used the surface to bottom density difference. They used a difference of $0.086 \mathrm{~kg} \mathrm{~m}^{-3}$ to distinguish stratified from non-stratified areas under present day conditions. However, the classification according to the maximal vertical density gradient as employed here requires to choosing a bit lower reference value.

We here use a reference value of $0.05 \mathrm{~kg} \mathrm{~m}^{-3} \mathrm{~m}^{-1}$ to distinguish areas of intense stratification from moderately stratified or non-stratified areas. This value has no empirical relationship to specific hydrodynamic or biogeochemical processes but was chosen to reflect the dynamics in areas of intense stratification and their response to climate change appropriately. This definition classifies the Skagerrak, 

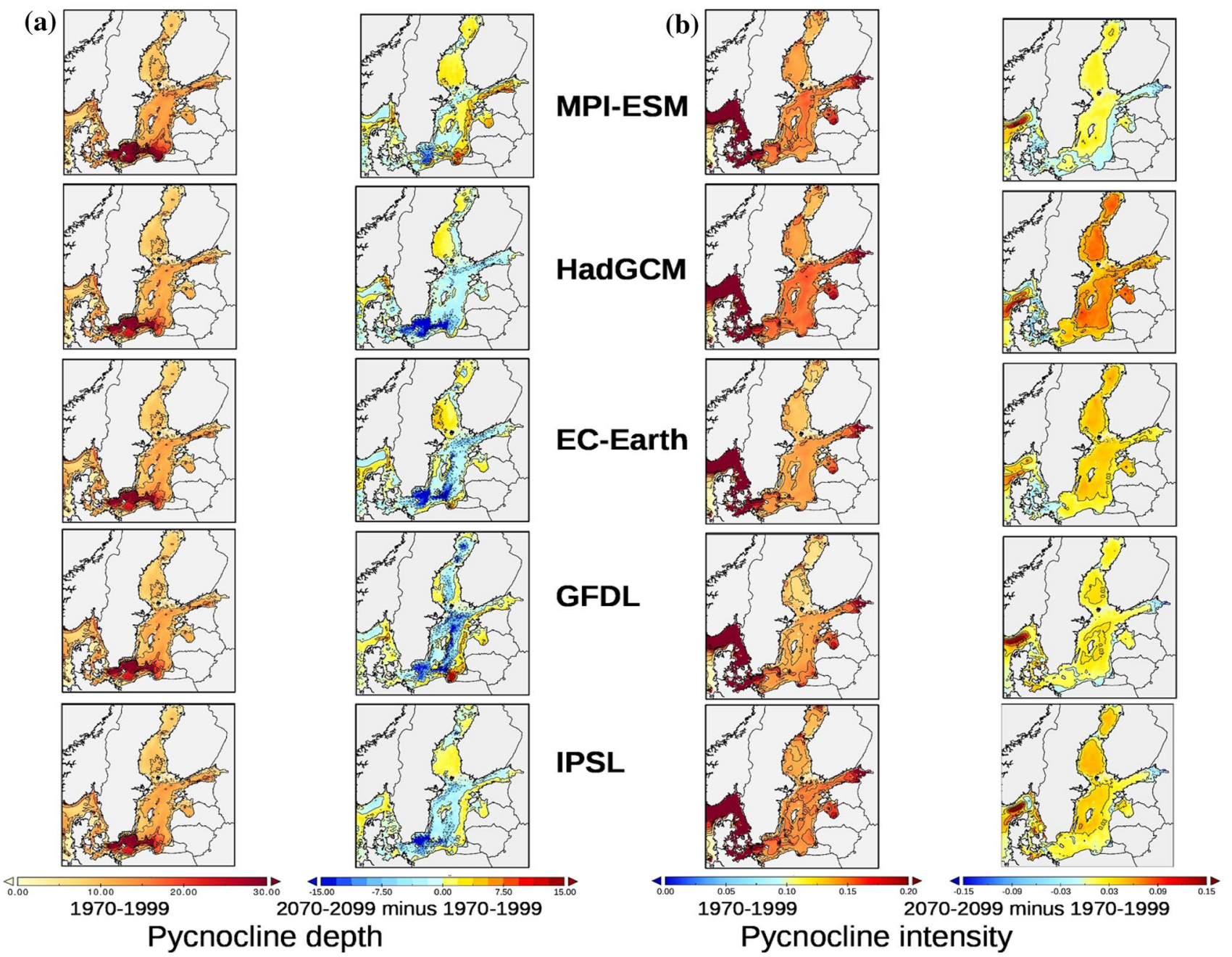

Fig. 8 a Average (1970-1999) summer pycnocline depth (m). Right same as left but difference between 2070-2099 minus 1970-1999. b Same as a but for pycnocline intensity $\left(\mathrm{kg} \mathrm{m}^{-3} \mathrm{~m}^{-1}\right)$

Kattegat and large parts of the Baltic Sea (with the exception of parts of the Bothnian Sea and the Bothnian Bay) as intensely stratified in the historical period in most of the ensemble members (Fig. 8b, left). In the Baltic Sea the total area of stratified water increases in all ensemble members (MPIESM $=23 \%$, HadGCM $=78 \%$, EC-EARTH $=100 \%$, GFDL $=36 \%$, IPSL $=53 \%$, Fig. 9a). Pycnocline intensity (Fig. 9c) and pycnocline depth (Fig. 9b) show decreasing trends. Hence the pycnocline becomes shallower but less intense in those areas where intensity exceeds the reference value. However, in all these areas there is a high amplitude low frequency variability.

\subsubsection{Influence of temperature and salinity on pycnocline intensity response}

We now aim to disentangle the individual contribution of water temperature and salinity changes on the response of pycnocline intensity to climate change. Near the surface both quantities are highly sensitive to the meteorological forcing (radiation, air temperature, net precipitation over the whole discharge area). Strategies to separate the influence of atmospheric forcing parameters on a given quantity such as the vertical density characteristics exist but are very cost intensive. Stein and Alpert (1993) demonstrated a factor separation technique proved for uncoupled simulations that involves many sensitivity experiments. However, this is by far too expensive when large ensembles have to be analyzed.

Therefore, in a first step we aim to investigate the effect of temperature changes and salinity changes separately on the vertical density structure. Thus, we recalculate the potential density field by using the salinity as calculated transiently during the model simulation but taking a monthly mean climatology for temperature that is fixed. The temperature climatology is calculated from the same run over a 20 -year reference period that represents the climate over the end of 
(a) Area of intensive pycnocline $>0.05 \mathrm{~kg} / \mathrm{m3} / \mathrm{m}$

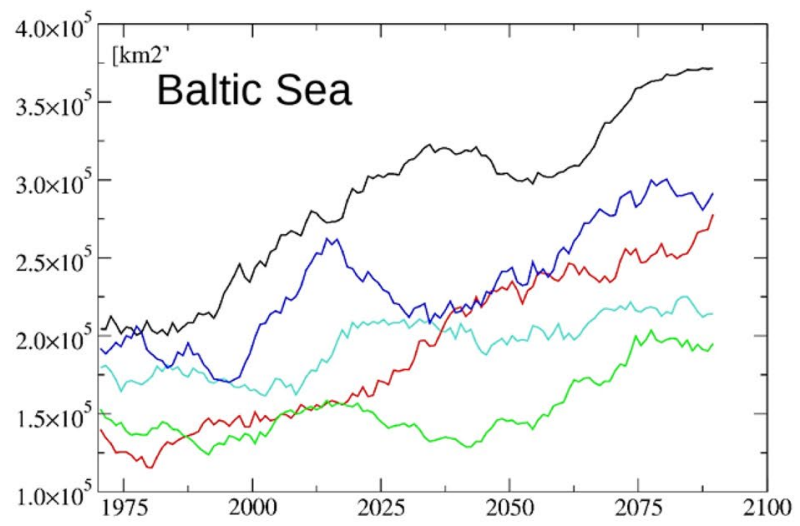

(b)
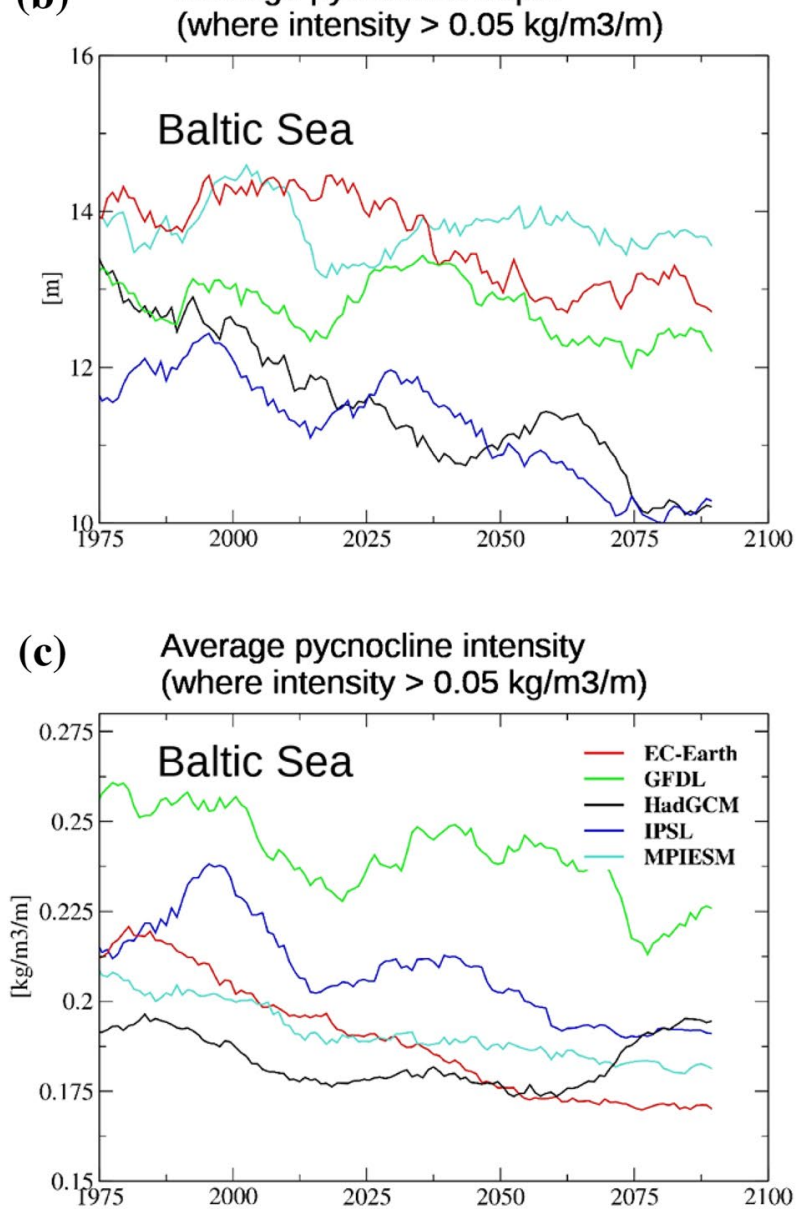

Fig. 9 Pycnocline characteristics averaged over areas with strong and intense pycnocline. Shown is a seasonal average over June, July, and August

the twentieth century (1980-1999). The resulting 3D density time series then reflects the individual influence of salinity changes on the vertical density structure. Correspondingly, the procedure was repeated using transient temperature (a)

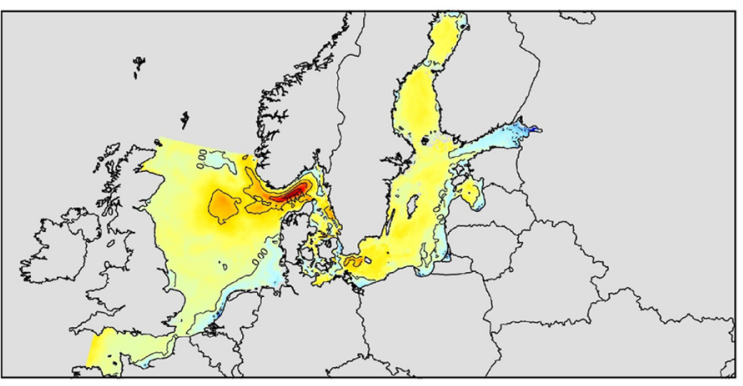

(c)

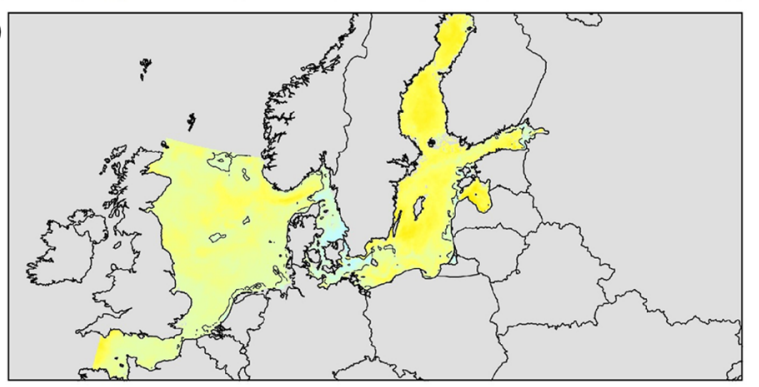

(c)

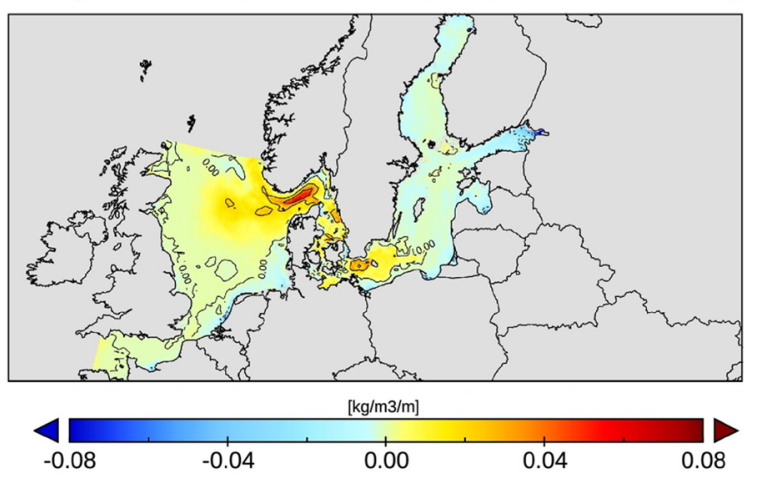

Fig. 10 Difference (2070-2099 minus 1970-1999) of pycnocline intensity $\left(\mathrm{kg} \mathrm{m}^{-3} \mathrm{~m}^{-1}\right)$ for a as simulated during model integration, b recalculated difference to extract the effect of temperature changes, and $\mathbf{c}$ recalculated difference to extract the effect of salinity changes on the density field. Displayed examplarily for the ensemble member MPIESM

changes and the fixed climatology for salinity which is used to infer the influence of temperature on density throughout the twenty-first century. Finally, from the resulting 3D density time series the pycnocline characteristics is recalculated.

Figure 10 compares the climate change signal of the original pycnocline (Fig. 10a) with climate change signal due to the influence of temperature (Fig. 10b) and salinity changes (Fig. 10c). As illustration for how the method works we here include also the North Sea. Visible inspection already indicates that the spatial pattern in the North Sea, Skagerrak, and Kattegat (Fig. 10a, original series) clearly resembles the pattern seen in the picture that reflects the changes in pycnocline intensity due to salinity changes (Fig. 10c). In the Baltic Sea however, a spatially rather smooth and widespread increase in intensity is seen (Fig. 10a) which well fits with the pattern seen in the change caused by temperature 
changes (Fig. 10b) while changes caused by salinity rather reflect a widespread weakening of pycnocline intensity (Fig. 10c). Thus, for the MPIESM ensemble member as displayed in Fig. 10, climate induced changes in the North Sea due to salinity changes appear more important than the effect of temperature changes whereas for the Baltic the opposite is true, i.e. temperature changes are more important.

In order to get a more quantitative estimation for the comparison of the visible spatial patterns we carried out a spatial correlation analysis. Thus, we calculated the spatial correlation coefficients between the original data set and that of the recalculated data sets reflecting the changes due to temperature and salinity changes. The results are presented in Table 2 for the Baltic Sea.

In the Baltic Sea three out of five ensemble members in the Baltic Sea point to salinity changes dominating the response of the pycnocline intensity (yellow highlighted cell pairs in Table 2) whereas two ensemble members highlight the importance of temperature changes. By contrast, in case of pycnocline depth the temperature induced changes (green highlighted cell pairs in Table 2) explain in all case more of the spatial variance than the salinity induced changes. Thus, the influence of temperature induced changes are primarily important for the change in the spatial pattern of pycnocline depth whereas salinity changes have a significant influence on pycnocline intensity and thus point to larger uncertainties in the model projections.

\section{Summary and discussion}

\subsection{Large-scale changes: overturning circulation and wind forcing}

So far, we have shown strong changes in surface salinity and temperature together with changes in the Baltic Sea meridional overturning circulation in the Bothnian Sea (R4 in Fig. 6c). Our results provide evidence that the circulation in the Baltic Sea becomes more wind driven while the deeper

Table 2 Spatial correlation analysis between the climate change signal in pycnocline characteristics (2070-2099 minus 1970-1999) as simulated and the climate change signal due to changes in temperature (T) and salinity (S) respectively

\begin{tabular}{|l|l|l|l|l|l|l|l|l|l|l|l|}
\hline \multicolumn{10}{|c|}{ Pycnocline Intensity } \\
\hline & MPI-ESM & \multicolumn{2}{|l|}{ HadGCM } & \multicolumn{2}{l|}{ EC-Earth } & \multicolumn{2}{l|}{ GFDL } & \multicolumn{2}{l|}{ IPSL } \\
\hline & S & T & S & T & S & T & S & T & S & T \\
\hline Baltic Sea & 0.81 & 0.76 & 0.80 & 0.93 & 0.79 & 0.91 & 0.86 & 0.23 & 0.73 & 0.58 \\
\hline \multicolumn{10}{|c|}{ Pycnocline Depth } \\
\hline Baltic Sea & 0.42 & 0.79 & 0.36 & 0.93 & 0.79 & 0.91 & 0.46 & 0.86 & 0.48 & 0.78 \\
\hline
\end{tabular}

To facilitate fast inspection cell pairs highlighted in yellow (green) indicate higher correlation between the salinity (temperature) forced changes in pycnocline intensity circulation cell gets more sluggish in the northern Baltic Proper (R2 in Fig. 6e) and salinity at depth reduces (Fig. 7a).

Interestingly, Hordoir et al. (2018) applied the downscaled RCP8.5 atmospheric forcing derived from the same global models EC-Earth and MPIESM as used in this study to drive an ocean only version of a somewhat different NEMO based ocean model version that is used here in interactive coupling with the atmosphere. Contrary to the results reported here the authors found a $15 \%$ decrease of the meridional overturning circulation in the southern Baltic at the end of the twenty-first century while the experiments described here are rather stable in the southern Baltic (Fig. 6b, R1). Hordoir et al. (2018) found the weaker overturning linked mainly to enhanced stratification in their experiments. However, Hordoir et al. (2018) did not consider climate induced changes in runoff as in this study which may explain the higher sensitivity of the overturning circulation against stratification in their simulation.

Another prominent feature is the increase in wind speed and northward extension of westerlies over the Atlantic sector. Figure S2 (supplementary material S2) indicates a shift in average summer wind speed over the Atlantic part covered by the regional atmosphere model. A distinct pattern is seen in four out of five ensemble members: (1) increased wind speeds around the Biscaya in the southern model domain. (2) Further to the North a belt with decreased speed is seen which extends differently far to the North. Finally a belt with increased wind speeds is seen over England and further to the North. Probably the pattern will be related to large-scale atmospheric changes such as changes in the strength and/ or the mean position of the Icelandic Low and the High over the Azores. However, in depth investigation about the changes in the atmosphere is beyond the scope of this study.

\subsection{Potential impact on biogeochemistry}

We have further shown that most regions become more stratified, i.e. the pycnocline intensifies almost everywhere and highly stratified areas are spreading. Although our model includes no biogeochemical model, the here described hydrographic changes can be expected to have substantial influence on the ecosystem. In the Baltic Sea the reduction of deep water salinity will on longer times scales probably lead to better oxygen conditions leading to less frequent hypoxia near the sea floor. On the other hand a stronger summer stratification may have negative impact on oxygen conditions during the warm season. Furthermore, Meier et al. (2012a) and Saraiva et al. (2019) showed that changes in the riverine nutrient input from agriculture and industrial sectors is here of greater importance than climate induced changes in stratification and circulation. 


\subsubsection{Nutrient cycling and productivity}

In the North Sea, the warming of water in the near surface layers will certainly stimulate growth rates of phytoplankton. In addition, higher water temperatures will accelerate the decomposition and remineralization of dead organic material by stimulating the microbiological loop. Thus, nutrients formally incorporated in particulate organic matter will be made available again faster. On the other hand, stronger stratification will tend to suppress the vertical nutrient transport into the euphotic layer which will decrease nutrient availability and limit primary production. The complex interaction of the above mentioned processes makes it very difficult to predict the response of primary production to climate warming so that even the sign of primary production change might be difficult to predict in a future climate (Taucher and Oschlies 2011).

In the Baltic Sea the intensification of the pycnocline may have less impact on the ecosystem because this sea is already under present day climate permanently stratified although also here the area with a intense pycnocline increases (Fig. 9a). Here, the changes in the pycnocline depth may be of greater importance. This applies especially for the Bornholm Sea where the strongest and most coherent shallowing of the pycnocline depth is registered (Fig. 8a). Figure 11 shows that here the pycnocline depth decreases between $\sim 6.5$ and $15 \mathrm{~m}$ (20 and 54\%, only MPIESM shows no significant trend). In HadGCM pycnocline depth shallows to $\sim 12 \mathrm{~m}$ at the end of the twenty-first century and thus, is close to the reported Secchi depth in the Bornholm Sea of $\sim 9 \mathrm{~m}$ (Fleming-Lethinen 2016). This implies that the pycnocline would penetrate further into the euphotic layer and may introduce nutrient limitation there. Most studies investigating the euphotic layer thickness and Secchi depth found a simple linear relationship in which the euphotic layer equals 2.5-3.0 times the Secchi depth (e.g. French et al. 1982; Mencfel 2011). This would imply the euphotic layer thickness of roughly 22-27 assuming a Secchi depth of $\sim 9 \mathrm{~m}$ (Fleming-Lethinen 2016) in the Bornholm Basin. However most of these relationships were derived from

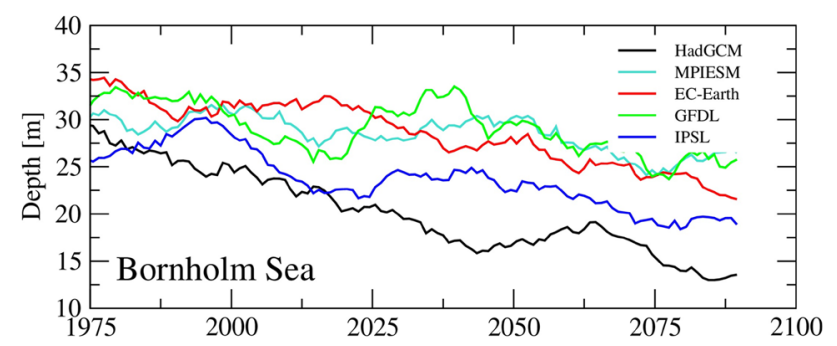

Fig. 11 Time series of pycnocline depth averaged over the Bornholm Sea Area definition is according to the basin definition by Meier et al. (1999). Shown is a 20 year running average measurements in freshwater lakes which are not necessarily applicable in the Bornholm Sea.

\subsubsection{Changes in water properties and implications for higher trophic species}

Many zooplankton species and fish species are restricted to certain habitats consisting of species specific ranges for salinity, temperature, and oxygen concentrations (e.g. Vuorinen et al. 2015; Jutila et al. 2005 for temperature dependence of Atlantic salmon in the northern Baltic). It is plausible to assume that the above described changes in water temperature and salinity will impact on the species habitats. Rather than providing a detailed analysis of habitats for individual species we here follow the more general approach of the Venice water type classification with specific modifications especially for the Baltic Sea ecosystem (Anonymous 1958). The Venice classification divides water types according to salinity ranges. According to this, we here calculate total average volumes of polyhaline $\left(30-18 \mathrm{~g} \mathrm{~kg}^{-1}\right), \alpha$-mesohaline $\left(18.0-10.0 \mathrm{~g} \mathrm{~kg}^{-1}\right), \beta$-mesohaline $\left(10.0-5.0 \mathrm{~g} \mathrm{~kg}^{-1}\right)$, $\alpha$-oligohaline (5.0-3.0 $\mathrm{g} \mathrm{kg}^{-1}$ ), and $\beta$-oligohaline (3.0-0.5) for the Baltic Sea east of $10^{\circ} \mathrm{E}$. The results are presented as volume time series in Fig. 12.

Polyhaline water favoring species will moderately benefit by climate change mainly as a result of the strong freshening in the Skagerrak-Kattegat region. Likewise, oligohaline species will substantially find better conditions in the future climate (Fig. 12d, e). Most prominent is the change in the $\beta$-oligohaline volume which is virtually absent under the historical period but rising significantly in all ensemble members starting at different times (Fig. 12e). In contrast to oligohaline habitats, mesohaline habitats will substantially shrink in the future climate. Wide areas that show up $\beta$-mesohaline, which constitute the biggest water type pool during the historical period properties, turn into the $\alpha$-oligohaline water type which pool is almost equally large in the future climate (in one case IPSL, it is even the largest pool).

Another important parameter characterizing the ecosystem is the marine biodiversity which also is often reported to be sensitive to climate change (e.g. Vuorinen et al. 2015; Worm and Lotze 2016; Ramirez et al. 2017). While in most marine environments the change in water temperature is considered an important factor for changing biodiversity, in brackish estuarine environments like the Baltic Sea salinity must be considered as important. Early attempts to relate biodiversity to salinity ranges have been developed on observations in the Baltic Sea (Remane diagram, Remane 1934) and often have been modified later according to a broader context (e.g. Whitfield et al. 2012). Most concepts indicate the salinity range between 5 and $7 \mathrm{~g} \mathrm{~kg}^{-1}$ associated with lowest number of species because many freshwater species and marine species are 

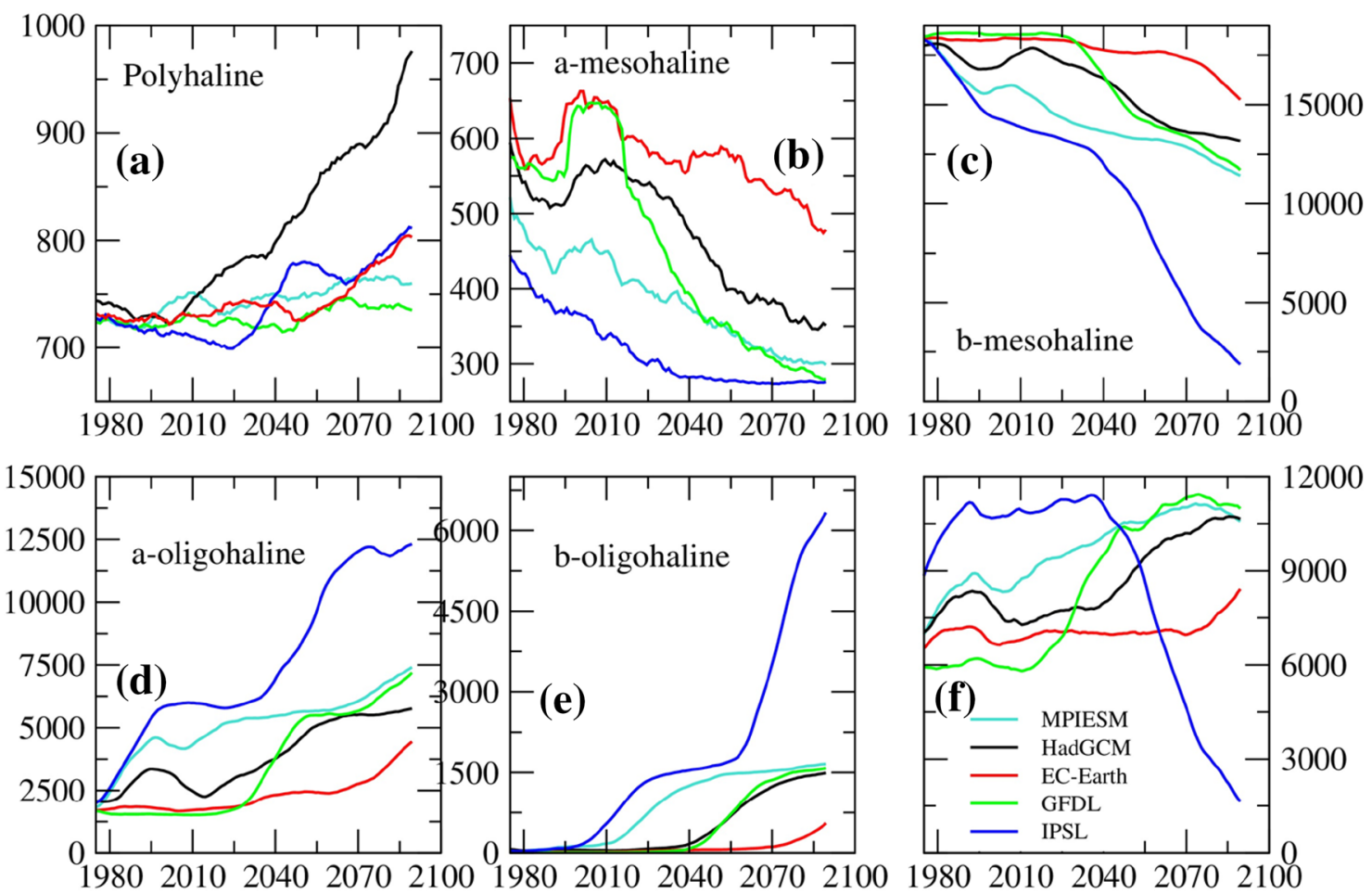

Fig. 12 a-e Time series of yearly average volume $\left(\mathrm{km}^{3}\right)$ for different water types according to the Venice classification system base on salinity. Polyhaline $=30-18 \mathrm{~g} \mathrm{~kg}^{-1}, \alpha$-mesohaline $\left(18.0-10.0 \mathrm{~g} \mathrm{~kg}^{-1}\right)$,

unable to tolerate water within this range (e.g. Whitfield et al. 2012). In Fig. $12 \mathrm{f}$ the volume of this water in the Baltic Sea is shown. In four out of five ensemble members, this volume increases between 18 and $45 \%$ while in the other one a strong decrease $78 \%$ is seen between the end of the twentieth and the end of twenty-first century. Interestingly, up to about year 1990 the evolution is more or less coherent with a first slight increase in the volume followed by a more or less pronounced decrease from 1990 to 2000. These results support previous evidence by Vuorinen et al. (2015) who showed similar shifts in the $5-7 \mathrm{~g} \mathrm{~kg}^{-1}$ water fraction for simulations forced by the older CMIP3 A1b and A2 climate scenarios.

Finally, it is noteworthy that many of the individual ensemble members show rather abrupt changes or regime shift like behavior. We exemplary emphasize the $\alpha$-oligohaline water volume simulated by IPSL and GFDL (green and blue series in Fig. 12d). Both exhibit a shift from about $2100-5000 \mathrm{~km}^{3}$ though the shift in GFDL occurs about 30 years later.

\section{Concluding remarks}

The here analyzed ensemble of coupled regional ocean-sea ice-atmosphere simulations following the RCP8.5 climate scenario revealed strong changes in atmospheric and ocean $\beta$-mesohaline (10.0-5.0 $\left.\mathrm{g} \mathrm{kg}^{-1}\right), \alpha$-oligohaline $\left(5.0-3.0 \mathrm{~g} \mathrm{~kg}^{-1}\right)$, and $\beta$-oligohaline (3.0-0.5). f Volumes relevant for biodiversity in the range $5-7 \mathrm{~g} \mathrm{~kg}^{-1}$

variables such as wind changes sea surface temperature and salinity. In general, the registered changes were coherent in a qualitative sense. Noteworthy, coherent responses comprise the strong freshening in the Skagerrak which is interconnected with a northward shift/northward extension of the westerlies and associated increase of wind speeds over central and northern Europe (Fig. 3).

The physical mechanism behind this is a stronger anticyclonic circulation in the Skagerrak in response to decreased occurrences of a NE wind regime (between 13.6 and -27\%) and stronger wind speeds in the westerly wind regime. This supports longer residence times in the Skagerrak cyclonic circulation which is likewise strengthened. This mixes fresher waters from the Norwegian coast to the Danish coast and thus amplifies freshening in the southern Skagerrak leading to the strongest freshening along the Danish coast in the entire model domain in most model ensemble.

The freshening at the surface together with increasing temperature of the uppermost ocean layers consistently leads to an intensification of the pycnocline which in most areas is associated with a shallower pycnocline in the water column (Fig. 8). Analysis of the response of the vertical density field provides evidence that changes in salinity are more important than changes in temperature for the found enhancement of pycnocline intensity. However, this might complicate 
predictions for the future evolution of pycnocline intensity on the regional scale because water salinity is more difficult to predict than temperature. Especially for the Baltic Sea it was shown that salinity changes were subject to substantial uncertainty in future scenarios (Meier 2015).

Further consistent responses are registered in the weakening of meridional overturning circulation in the northern Baltic Proper and the Bothnian Sea (Fig. 6c, e). However, despite the qualitative agreement of the here described changes the quantitative change may differ substantially among ensemble members which certainly reflects the uncertainty due to the driving global models. However, the above mentioned coherent responses in our ensemble indicate at least some reliability based on the process level. Thus, besides the investigation of various sources of uncertainties in regional ensembles (not focused in this study), this study argues for a more profound understanding of processes and causal chain of interconnected changes between the regions of interest and the large-scale drivers of changes that are in most cases far remote from the regions of interest.

With respect to the marine biogeochemistry the intensifying pycnocline and warming waters may worsen the problems of hypoxic areas and strong cyanobacteria blooms in the Baltic Sea in future climates. However, other factors such as future anthropogenic eutrophication scenarios may be more important (Saraiva et al. 2018) and can only be tested with a coupled biogeochmical model. With respect to higher trophic species such as fish the most severe changes are expected for the Baltic Sea where the freshening turns large volume of water masses from mesohaline to oligohaline conditions. This will very likely affect species compositions and biodiversity as well in the future.

Finally, our ensemble considers only the time up to 2100. As we here focused on the strongest warming scenario RCP8.5 within the CMIP5 framework the considered period is certainly too short to get the full response to climate change of the Baltic Sea. In the framework of the ongoing phase of CMIP6 this fact is accounted for by including extension runs up to 2300 into the ScenarioMIP protocol (O’Neill et al. 2016).

Acknowledgements The research presented in this study is part of the Baltic Earth program (Earth System Science for the Baltic Sea region, see http://www.baltic.earth) and was funded by the Swedish Research Council for Environment, Agricultural Sciences and Spatial Planning (FORMAS) within the project "Cyanobacteria life cycles and nitrogen fixation in historical reconstructions and future climate scenarios (1850-2100) of the Baltic Sea" (Grant no. 214-2013-1449). Further funding was obtained from the MERCATOR CMEMS Service Evolution 66-SE-CALL2 "Regionally downscaled climate projections for the Baltic and North Seas (CLIMSEA)". Furher funding was obtained from the project CoClime. Project CoCliME is part of ERA4CS, an ERA-NET initiated by JPI Climate, and funded by EPA (IE), ANR (FR), BMBF (DE), UEFISCDI (RO), RCN (NO) and FORMAS (SE), with co-funding by the European Union (Grant 690462). Further funding was obtained from the project ClimeMarine founded by the Swedish Research Council Formas within the framework of the National Research Programme for Climate (Grant no. 2017-01949).

Open Access This article is distributed under the terms of the Creative Commons Attribution 4.0 International License (http://creativeco mmons.org/licenses/by/4.0/), which permits unrestricted use, distribution, and reproduction in any medium, provided you give appropriate credit to the original author(s) and the source, provide a link to the Creative Commons license, and indicate if changes were made.

\section{References}

Anonymous (1958) The Venice system of the classification of marine waters according to salinity. Limnol Oceanogr 3(3):346-347. https ://doi.org/10.4319/lo.1958.3.3.0346

Balmaseda MA, Mogensen K, Weaver AT (2013) Evaluation of the ECMWFocean reanalysis system ORAS4. Q J R Meteor Soc 139(674):1132-1161. https://doi.org/10.1002/qj.2063

Bersch M, Gouretski V, Sadikni R, Hinrichs I (2013) KLIWAS north sea climatology of hydrographic data (version 1.0). World data center for climate (WDCC). https://doi.org/10.1594/WDCC/ KNSC_hyd_v1.0

Berg P, Döscher R, Koenigk T (2015) On the effects of constraining atmospheric circulation in a coupled atmosphere-ocean Arctic regional climate model. Clim Dyn. https://doi.org/10.1007/s0038 2-015-2783-y

Bopp L, Resplandy L, Orr JC, Doney SC, Dunne JP, Gehlen M, Halloran P, Heinze C, Ilyina T, Seferian R, Tjiputra J, Vichi M (2013) Multiple stressors of ocean ecosystems in the 21 st century projections with CMIP5 models. Biogeosciences 10:6225-6245

Bülow K, Dieterich C, Elizalde A, Gröger M, Heinrich H, Huettl-Kabus S, Klein B, Mayer B, Meier HEM, Mikolajewicz U, Narayan N, Pohlmann T, Rosenhagen G, Schimanke S, Sein DV, Su J (2014) Comparison of three regional coupled ocean atmosphere models for the North Sea under today's and future climate conditions. KLIWAS Schriftenreihe. 27/2014. https://doi.org/10.5675/kliwa s_27/2014

Christensen KH, Sperrevik AK, Broström G (2018) On the variability in the onset of the norwegian coastal current. J Phys Oceanogr. https://doi.org/10.1175/jpo-d-17-0117.1

Collins M, Knutti R, Arblaster J, Dufresne J-L, Fichefet T, Friedlingstein P, Gao X, Gutowski WJ, Johns T, Krinner G, Shongwe M, Tebaldi C, Weaver AJ, Wehner M (2013) Long-term climate change: projections, commitments and irreversibility. In: Stocker TF, Qin D, Plattner G-K, Tignor M, Allen SK, Boschung J, Nauels A, Xia Y, Bex V, Midgley PM (eds) Climate change 2013: the physical science basis. Contribution of Working Group I to the Fifth Assessment Report of the Intergovernmental Panel on Climate Change. Cambridge University Press, Cambridge

Dethloff K, Rinke A, Lynch A, Dorn W, Saha S, Handorf D (2012) Arctic regional climate models, Arctic climate change: the ACSYS decade and beyond. Book Ser Atmos Oceanogr Sci Libr 43:325-356. https://doi.org/10.1007/978-94-007-2027-5_8

Dieterich C, Wang S, Schimanke S, Gröger M, Klein B, Hordoir R, Samuelsson P, Liu Y, Axell L, Höglund A, Meier HEM (2019) Surface heat budget over the North Sea in climate change simulations. Atmosphere 10(5):272. https://doi.org/10.3390/atmos 10050 272

Donnelly C, Andersson JCM, Arheimer B (2016) Using flow signatures and catchment similarities to evaluate the e-hype multi-basin model across europe. Hydrol Sci J 61(2):255-273. https://doi. org/10.1080/02626667.2015.1027710 
Döös K, Meier HEM, Döscher R (2004) The Baltic haline conveyor belt or the overturning circulation and mixing in the Baltic. Ambio 33:261-266

Egbert GD, Erofeeva SY, Ray RD (2010) Assimilation of altimetry data for nonlinear shallow-water tides: quarter-diurnal tides of the Northwest European Shelf. Cont Shelf Res 30(6):668-679. https ://doi.org/10.1016/j.csr.2009.10.011

Fleming-Lethinen V (2016) Secchi depth in the Baltic Sea-an indicator of eutrophication. University of Helsinki, Faculty of Biological and Environmental Sciences, Helsinki. pp 42. https://helda.helsi nki.fi/bitstream/handle/10138/168525/Secchide.pdf? sequence $=1$. Accessed 30 July 2019

French RH, Cooper JJ, Vigg S (1982) Secchi depth relationships. Water Resour Bull 18(1):121-123

Giorgi F, Jones C, Asrar GR (2009) Addressing climate information needs at the regional level: the CORDEX framework. WMO Bull 58:175-183

Gröger M, Maier-Reimer E, Mikolajewicz U, Moll A, Sein D (2013) NW European shelf under climate warming: implications for open ocean-shelf exchange, primary production, and carbon absorption. Biogeosciences 10(6):3767-3792. https://doi. org/10.5194/bg-10-3767-2013

Gröger M, Dieterich C, Meier HEM, Schimanke S (2015) Thermal air-sea coupling in hindcast simulations for the North Sea and Baltic Sea on the NW European shelf. Tellus Ser A Dyn Meteorol Oceanogr 67:26911. https://doi.org/10.3402/tellu sa.v67.26911

Gutowski WJ, Giorgi F, Timbal B, Frigon A, Jacob D, Kang H-S, Raghavan K, Lee B, Lennard C, Nikulin G, O'Rourke E, Rixen M, Solman S, Stephenson T, Tangang F (2016) WCRP COordinated Regional Downscaling EXperiment (CORDEX): a diagnostic MIP for CMIP6. Geosci Model Dev 9:4087-4095. https ://doi.org/10.5194/gmd-9-4087-2016

Hand R, Keenlyside NS, Omrani NE, Greatbatch RJ (2018) The role of local sea surface temperature pattern changes in shaping climate change in the North Atlantic sector. Clim Dyn. https://doi. org/10.1007/s00382-018-4151-1

Hjøllo SS, Skogen Morten D, Svendsen Einar (2009) Exploring currents and heat within the North Sea using a numerical model. J Mar Syst 78(1):180-192. https://doi.org/10.1016/j.jmars ys.2009.06.001 (ISSN 0924-7963)

Ho-Hagemann HTM, Gröger M, Rockel B, Zahn M, Geyer B, Meier HEM (2017) Effects of air-sea coupling over the North Sea and the Baltic Sea on simulated summer precipitation over Central Europe. Clim Dyn 49:3851. https://doi.org/10.1007/s0038 2-017-3546-8

Holt J, Wakelin S, Lowe J, Tinker J (2010) The potential impacts of climate change on the hydrography of the northwest European continental shelf. Prog Oceanogr 86:361-379

Holt J, Butenschön M, Wakelin SL, Artioli Y, Allen JI (2012) Oceanic controls on the primary production of the northwest European continental shelf: model experiments under recent past conditions and a potential future scenario. Biogeosciences 9:97-117. https://doi.org/10.5194/bg-9-97-2012

Holt J, Schrum C, Cannaby H, Daewel U, Allen I, Artioli Y, Bopp L, Butenschon M, Fach B, Harle J, Pushpadas D (2016) Potential impacts of climate change on the primary production of regional seas: a comparative analysis of five European seas. Prog Oceanogr 140:91-115

Hordoir R, Höglund A, Pemberton P, Schimanke S (2018) Sensitivity of the overturning circulation of the Baltic Sea to climate change, a numerical experiment. Clim Dyn 50:1425. https://doi. org/10.1007/s00382-017-3695-9

Jacob D et al (2014) EURO-CORDEX new high resolution climate change projections for European impact research. Reg Environ Change 14:563-578
Jeworrek J, Wu L, Dieterich C, Rutgersson A (2017) Characteristics of convective snow bands along the Swedish east coast. Earth Syst Dyn 8:163-175. https://doi.org/10.5194/esd-8-163-2017

Jutila E, Jokikokko E, Julkunen M (2005) The smolt run and postsmolt survival of Atlantic salmon, Salmo salar L., in relation to early summer water temperatures in the northern Baltic sea. Ecol Freshw Fish 14:69-78

Koenigk T, Berg P, Döscher R (2015) Arctic climate change in an ensemble of regional CORDEX simulations. Polar Res 34:24603. https://doi.org/10.3402/polar.v34.24603

Kotlarski S, Lüthi D, Schär C (2015) The elevation dependency of 21st century European climate change: an RCM ensemble perspective. Int J Climatol. https://doi.org/10.1002/joc.4254

Lau WK-M, Wu H-T, Kim K-M (2013) A canonical response of precipitation characteristics to global warming from CMIP5 models. Geophys Res Lett 40:3163-3169

Levang SJ, Schmitt RW (2015) Centennial changes of the global water cycle in CMIP5 models. J Clim 28(16):6489-6502. https://doi. org/10.1175/jcli-d-15-0143.1

Madec G (2011) NEMO ocean engine. User manual 3.3. IPSL, Paris

Madec G, The NEMO Team (2012) "NEMO ocean engine": Note du Pole de modélisation de l'Institut Pierre-Simon Laplace, France, No 27, ISSN no 1288-1619

Mathis M, Pohlmann T (2014) Projection of physical conditions in the North Sea for the 21st century. Clim Res 61:1-17. https://doi. org/10.3354/cr01232

Mathis M, Elizalde A, Mikolajewicz U (2017) Which complexity of regional climate system models is essential for downscaling anthropogenic climate change in the Northwest European Shelf? Clim Dyn. https://doi.org/10.1007/s00382-017-3761-3

Matthäus W, Franck H (1992) Characteristics of major Baltic inflowsa statistical analysis. Cont Shelf Res 12:1375-1400

Meier HEM (2007) Modeling the pathways and ages of inflowing salt-and freshwater in the Baltic Sea. Estuar Coast Shelf Sci 74(4):610-627. https://doi.org/10.1016/j.ecss.2007.05.019

Meier HEM (2015) Projected change-marine physics. In: BACC II Author Team (ed) Second assessment of climate change for the Baltic Sea basin, Chap 13. Regional Climate Studies, Springer, Berlin. https://doi.org/10.1007/978-3-319-16006-1

Meier HEM, Kauker F (2003) Modeling decadal variability of the Baltic Sea: 2. Role of freshwater inflow and large-scale atmospheric circulation for salinity. J Geophys Res Oceans. https://doi. org/10.1029/2003JC001799

Meier HEM, Saraiva S (2019) Projected oceanographical changes in the Baltic Sea until 2100. Oxf Res Encycl Clim Sci (in press)

Meier HEM, Döscher R, Coward AC, Nycander J, Döös K (1999) RCO-Rossby Centre regional Ocean climate model: model description (version 1.0) and first results from the hindcast period 1992/93. Reports Oceanography No. 26, SMHI, Norrköping, Sweden, $\mathrm{p} 102$

Meier HEM, Andersson HC, Eilola K, Gustafsson BG, Kuznetsov I, Müller-Karulis B et al (2011) Hypoxia in future climates: a model ensemble study for the Baltic Sea. Geophys Res Lett. https://doi. org/10.1029/2011GL049929

Meier HEM, Hordoir R, Andersson H, Dieterich C, Eilola K, Gustafsson BG, Höglund A, Schimanke S (2012a) Modeling the combined impact of changing climate and changing nutrient loads on the Baltic Sea environment in an ensemble of transient simulations for 1961-2099. Clim Dyn 39:2421-2441. https://doi. org/10.1007/s00382-012-1339-7

Meier HEM, Müller-Karulis B, Andersson HC, Dieterich C, Eilola K, Gustafsson BG, Höglund A, Hordoir R, Kuznetsov I, Neumann $T$ et al (2012b) Impact of climate change on ecological quality indicators and biogeochemical fluxes in the Baltic Sea: a multi-model ensemble study. Ambio 41:558-573. https://doi. org/10.1007/s13280-012-0320-3 
Meier HEM, Andersson HC, Arheimer B, Blenckner T, Chubarenko B, Donnelly C, Eilola K, Gustafsson BG, Hansson A, Havenhand J et al (2012c) Comparing reconstructed past variations and future projections of the Baltic Sea ecosystem-first results from multimodel ensemble simulations. Environ Res Lett 7:034005. https:// doi.org/10.1088/1748-9326/7/3/034005

Meier HEM, Edman M, Eilola K, Placke M, Neumann T, Andersson H, Brunnabend S-E, Dieterich C, Frauen C, Friedland R, Gröger M, Gustafsson BG, Gustafsson E, Isaev A, Kniebusch M, Kuznetsov I, Müller-Karulis B, Omstedt A, Ryabchenko V, Saraiva S, Savchuk OP (2018a) Assessment of eutrophication abatement scenarios for the Baltic Sea by multi-model ensemble simulations. Front Mar Sci 5:440. https://doi.org/10.3389/fmars.2018.00440

Meier HEM, Väli G, Naumann M, Eilola K, Frauen C (2018b) Recently accelerated oxygen consumption rates amplify deoxygenation in the Baltic Sea. J Geophys Res Oceans 123(5):3227-3240. https:// doi.org/10.1029/2017JC013686

Mencfel R (2011) Relationship between range of euphotic zone and visibility of Secchi disc in three lakes of Leczna-Wlodawa lake district, Teka Kom. Ochr. Kszt. Środ. Przyr.-OL PAN, 2011, 8, pp 97-103. http://www.pan-ol.lublin.pl/wydawnictwa/TOchr 8/Mencfel.pdf. Accessed 30 July 2019

Mikolajewicz U, Gröger M, Maier-Reimer E, Schurgers G, Vizcaino $\mathrm{M}$, Winguth A (2007) Long-term effects of anthropogenic $\mathrm{CO}_{2}$ emissions simulated with a complex earth system model. Clim Dyn 28:599. https://doi.org/10.1007/s00382-006-0204-y

Mohrholz V (2018) Major baltic inflow statistics revised. Front Mar Sci 5:384. https://doi.org/10.3389/fmars.2018.00384

Neumann T (2010) Climate-change effects on the Baltic Sea ecosystem: a model study. J Mar Syst 81:213-224

Neumann T, Friedland R (2011) Climate change impacts on the BalticSea. In: Schernewski G, Hofstede J, Neumann T (eds) Global change and Baltic coastal zones, vol 1. Coastal research library. Springer Science + Business Media, Berlin, pp 23-32

Neumann T, Eilola K, Gustafsson B, Muller-Karulis B, Kuznetsov I, Meier HEM, Savchuk OP (2012) Extremes of temperature, oxygen and blooms in the Baltic Sea in a changing climate. Ambio 41:574-585

Notz D (2015) How well must climate models agree with observations? Philos Trans R Soc A 373:20140164. https://doi. org/10.1098/rsta.2014.016

Omstedt A, Edman M, Claremar B, Frodin P, Gustafsson E, Humborg C, Hägg H, Mörth M, Rutgersson A, Schurgers G, Smith B, Wällstedt T, Yurova A (2012) Future changes in the Baltic Sea acid-base $(\mathrm{pH})$ and oxygen balances. Tellus Ser B Chem Phys Meteorol 64:1. https://doi.org/10.3402/tellusb.v64i0.19586

O'Neill B et al (2016) The scenario model intercomparison project (scenarioMIP) for CMIP6. Geosci Model Dev. https://doi. org/10.5194/gmd-2016-84

Pätsch J, Burchard H, Dieterich C, Gräwe U, Gröger M, Mathis M, Kapitza H, Bersch M, Moll A, Pohlmann T, Su J, Ho-Hagemann HTM, Schulz A, Eden C (2017) An evaluation of the North Sea circulation in global and regional models relevant for ecosystem simulations. Ocean Model. https://doi.org/10.1016/j.ocemo d.2017.06.005

Pushpadas D, Schrum C, Daewel U (2015) Projected climate change effects on North Sea and Baltic Sea: CMIP3 and CMIP5 modelbased scenarios. Biogeosci Discuss 12:12229-12279

Ramirez F, Afán I, Davis LS, Chiardia A (2017) Climate impacts on global hot spots of marine biodiversity. Sci Adv. https://doi. org/10.1126/sciadv. 1601198

Remane A (1934) Die Brackwasserfauna. Verhandlungen Der Deutschen Zoologischen Gesellschaft 36:34-74

Saraiva S, Markus Meier HE, Andersson H, Höglund A, Dieterich C, Gröger M, Hordoir R, Eilola K (2018) Baltic Sea ecosystem response to various nutrient load scenarios in present and future climates. Clim Dyn. https://doi.org/10.1007/s00382-018-4330-0

Saraiva S, Meier HEM, Andersson HC, Höglund A, Dieterich C, Gröger M et al (2019) Uncertainties in projections of the Baltic Sea ecosystem driven by an ensemble of global climate models. Front Earth Sci 6:244. https://doi.org/10.3389/feart.2018.00244

Schrum C (2017) Regional climate modeling and air-sea coupling. Clim Sci Oxf Res Encycl 1:1. https://doi.org/10.1093/acref ore/9780190228620.013.3

Schrum C, Lowe J, Meier HEM, Grabemann I, Holt J, Mathis M, Pohlmann T, Skogen MD, Sterl A, Wakelin S (2016) Projected change-North Sea. In: Quante M, Colijn F (eds) North Sea Region climate change assessment. Springer, Berlin, pp 175217. https://doi.org/10.1007/978-3-319-39745-0_6

Sein DV, Mikolajewicz U, Gröger M, Fast I, Cabos W, Pinto JG, Hagemann S, Semmler T, Izquierdo A, Jacob D (2015) Regionally coupled atmosphere ocean sea ice marine biogeochemistry model ROM: 1. Description and validation. J Adv Model Earth Syst. https://doi.org/10.1002/2014ms000357

Sein DV, Gröger M, Cabos W, Alvarez F, Hagemann S, Pinto J, Izquierdo A, Koldunov NV, Dvornikov AY, Limareva N, Martinez B, Jacob D (2018) Regionally coupled atmosphere-oceanmarine biogeochemistry model ROM: 2 . Studying the climate change signal in the North Atlantic and Europe. J Adv Earth Syst Model (in revision)

Stein U, Alpert P (1993) Factor separation in numerical simulations. J Atmos Sci 50:2107-2115. https://doi.org/10.1175/15200469(1993)050\%3c2107:fsins\%3e2.0.co;2

Steinacher M, Joos F, Frolicher TL, Bopp L, Cadule P, Cocco V, Doney SC, Gehlen M, Lindsay K, Moore JK, Schneider B, Segschneider J (2010) Projected 21st century decrease in marine productivity: a multi-model analysis. Biogeosciences 7:9791005. https://doi.org/10.5194/bg-7-979-2010

Strandberg G, Bärring L, Hansson L, Jansson C, Jones C, Kjellström E et al (2014) CORDEX scenarios for Europe from the Rossby Centre regional climate model RCA4. Reports meteorology and climatology, 116, SMHI, SE-60176 Norrköping, Sverige. https ://www.smhi.se/polopoly_fs/1.90273!/Menu/general/extGroup/ attachmentColHold/mainCol1/file/RMK_116.pdf. Accessed 30 July 2019

Taucher J, Oschlies A (2011) Can we predict the direction of marine primary production change under global warming? Geophys Res Lett. https://doi.org/10.1029/2010GL045934

Taylor KE, Stouffer RJ, Meehl GA (2012) An overview of CMIP5 and the experiment design. Bull Am Meteorol Soc. https://doi. org/10.1175/BAMS-D-11-00094.1

Tian T, Boberg F, Bössing Christensen O, Hesselbjerg Christensen J, She J et al (2013) Resolved complex coastlines and land-sea contrasts in a high-resolution regional climate model: a comparative study using prescribed and modelled SSTs. Tellus A 2013(65):19951. https://doi.org/10.3402/tellusa.v65i0.19951

Tinker J, Lowe J, Pardaens A, Holt J, Barciela R (2016) Uncertainty in climate projections for the 21 st century northwest European shelf seas. Prog Oceanogr 148:56-73

Valcke S (2013) The OASIS3 coupler: a European climate modelling community software. Geosci Model Dev 6(2):373-388. https:// doi.org/10.5194/gmd-6-373-2013

Väli G, Meier HEM, Elken J (2013) Simulated halocline variability in the Baltic Sea and its impact on hypoxia during 1961-2007. J Geophys Res 118:6982-7000. https://doi.org/10.1002/2013J C009192

van Leeuwen S, Tett P, Mills D, van der Molen J (2015) Stratified and non-stratified areas in the North Sea: long-term variability and biological and policy implications. J Geophys Res Oceans 120:4670-4686. https://doi.org/10.1002/2014jc010485 
van Pham TV, Brauch J, Frueh B, Ahrens B (2017) Simulation of snowbands in the Baltic Sea area with the coupled atmosphere-ocean-ice model COSMO-1309 CLM/NEMO. Meteorol Z 26(1):71-82. https://doi.org/10.1127/metz/13102016/0775

Vancoppenolle M, Fichefet T, Goosse H, Bouillon S, Madec G et al (2009) Simulating the mass balance and salinity of arctic and Antarctic sea ice. Ocean Model 2009(27):33-53

Vuorinen I, Hänninen J, Rajasilta M, Laine P, Eklund J, MontesinoPouzols F, Corona F, Junker K, Meier HEM, Dippner JW (2015) Scenario simulations of future salinity and Ecological Consequences in the Baltic Sea and adjacent North Sea areas-implications for environmental monitoring. Ecol Ind 50:196-205

Wang S, Dieterich C, Döscher R, Höglund A, Hordoir R, Meier HEM, Samuelsson P, Schimanke S (2015) Development of a new regional coupled atmosphere-ocean model in the North
Sea and Baltic Sea. Tellus A 67:24284. https://doi.org/10.3402/ tellusa.v67.24284

Whitfield AK, Elliott M, Basset A, Blaber SJM, West RJ (2012) Paradigms in estuarine ecology - a review of the Remane diagram with a suggested revised model for estuaries. Estuar Coast Shelf Sci 97:78-90

Worm B, Lotze H (2016) Marine biodiversity and climate change. In: Letcher TM (ed) Climate change. Elsevier, New York, pp 195212. https://doi.org/10.1016/b978-0-444-63524-2.00013-0

Publisher's Note Springer Nature remains neutral with regard to jurisdictional claims in published maps and institutional affiliations. 